\title{
TÜRK PATENT HUKUKU AÇISINDAN ÇALIŞAN BULUŞLARINDA HAK SAHİPLİĞİ VE ÇALIŞANIN BEDEL HAKKI
}

THE RIGHTS OF OWNERSHIP AND REMUNERATION IN EMPLOYEES' INVENTION IN

\section{Hakan KOÇAK*}

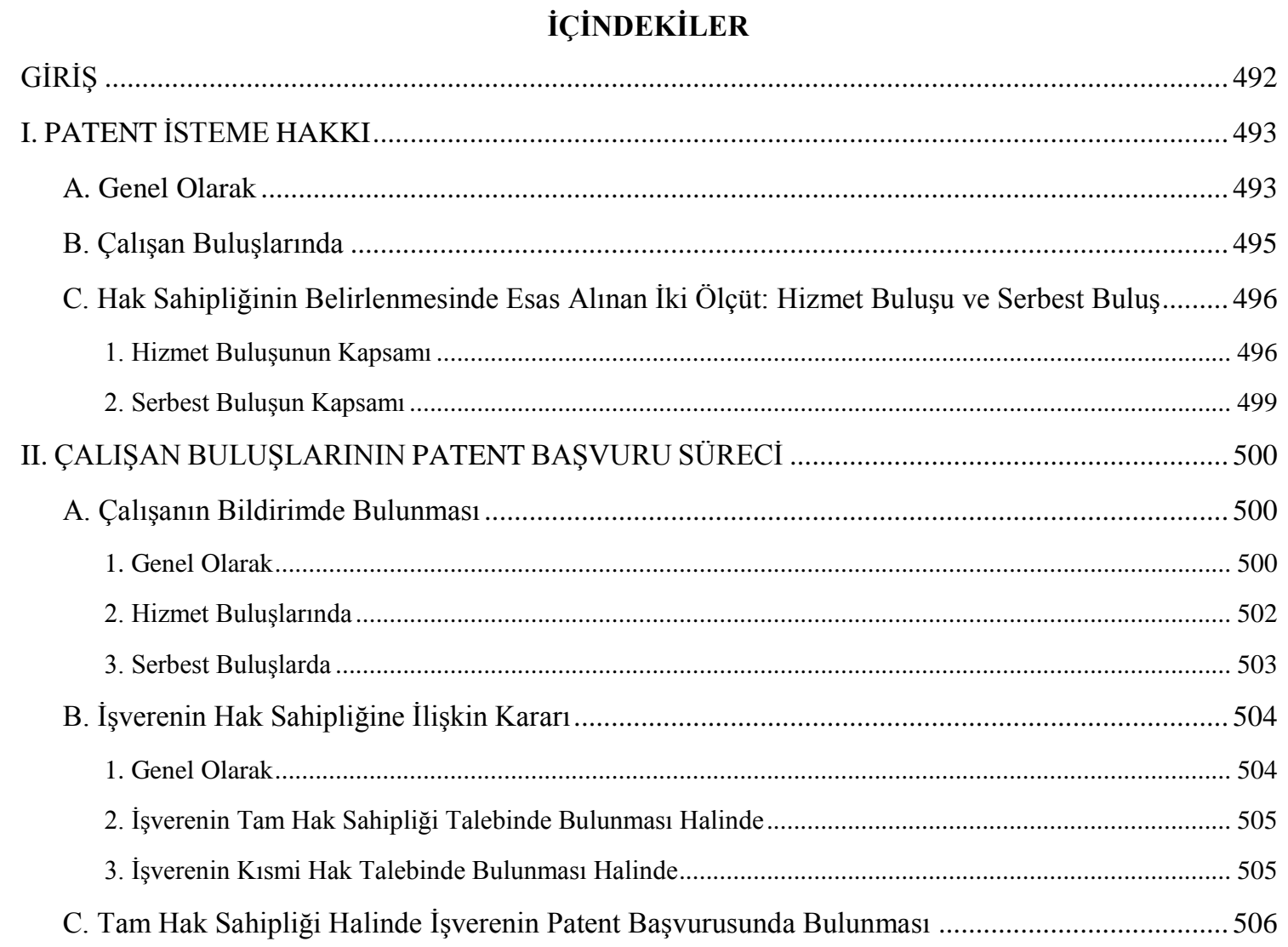

DOI: $10.32957 /$ hacettepehdf.623846

Makalenin Geliş Tarihi: 24.09.2019

Makalenin Kabul Tarihi: 03.11.2019

* Araştırma Görevlisi. Ankara Sosyal Bilimler Üniversitesi Hukuku Fakültesi Ticaret Hukuku Anabilim Dalı. E-posta: hakan.kocak@asbu.edu.tr

ORCID: 0000-0002-9591-028X 


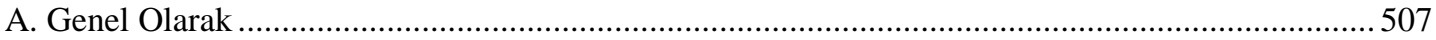

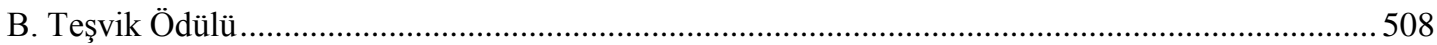

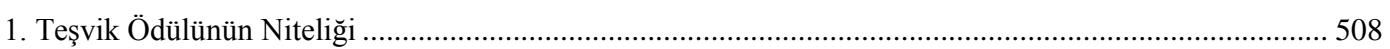

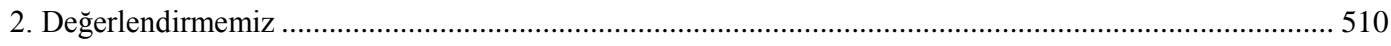

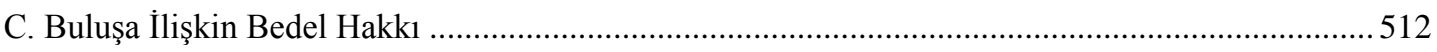

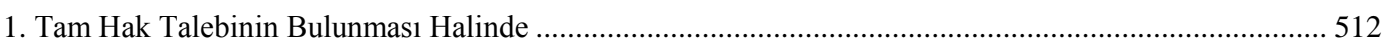

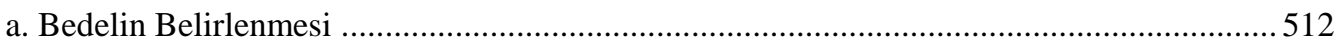

aa. Mevzuata Göre Bedelin Belirlenmesi .............................................................. 512

aaa. Kamu Kurum ve Kuruluşlarında Çalışanlar Yönünden .............................................512

bbb. Diğer Çalışan Buluşları Yönünden ..................................................................... 513

bb. Bedelin Sözleşme ile Belirlenmesi ............................................................................. 518

b. Bedelin Ödenmesi .................................................................................................. 521

2. İşverenin Kısmi Hak Talebinin Bulunması Halinde ............................................................................. 523

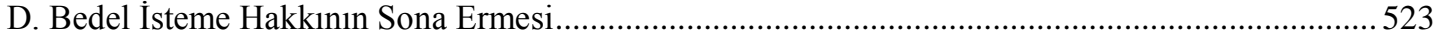

E. Bedele İlişkin Uyuşmazlıkların Çözümü.............................................................................525

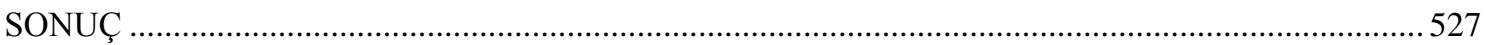

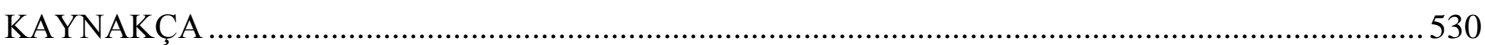

ÖZ

Patent isteme hakkı, kural olarak buluşu gerçekleştiren kişiye aittir. Ancak bu hakkın, kanunla bir başka kimseye tanınması veya buluş sahibi tarafından üçüncü kişilere devredilmesi mümkündür. Uluslararası hukukta, çalışanların gerçekleştirdiği buluşlara ilişkin patent isteme hakkının çalışana mı işverene mi ait olacağı konusunda yeknesak bir kural veya ilke bulunmamaktadır. Türk hukukunda belirli şartların bulunması halinde, buluşa yönelik patent isteme hakkına sahip olmak için işverene bir tercih hakkı tanınmıştır. Buna göre, çalışan bir buluş gerçekleştirdiğinde, bu durumu gecikmeksizin işverene bildirmekle yükümlüdür. Çalışanın buluşa ilişkin bildirim yükümlülüğünü yerine getirmesi üzerine işveren kanunda belirlenen süre içinde tercih hakkını kullanabilmektedir.

İşverenin patent isteme hakkını elde etmesi halinde bedel ödeme yükümlülüğü doğmaktadır. 6769 sayılı Kanunda işverenin buluş üzerinde tam hak sahipliği talebinde bulunması halinde ödeyeceği bedele ilişkin birtakım ilkeler kabul edilmiştir. Bu ilkeler dikkate alınarak 29.09.2017 tarih ve 30195 sayılı Yönetmelik’te ödenecek bedele ilişkin ayrıntılı düzenlemeler öngörülmüştür. Kanunda belirtilmemesine rağmen Yönetmelikte ayrıca çalışana teşvik ödülü hakkı tanınmıştır. 
Bu makalede, Türk patent hukukunda çalışan buluşlarına ilişkin düzenlemeler ve 6769 sayılı Kanun ile 29.09.2017 tarih ve 30195 sayılı Yönetmelik’in çalışan buluşları hakkında getirdiği yenilikler incelenmektedir. Ayrıca, Yönetmelik’teki çalışanın bedel isteme hakkına, bildirim yükümlülüğüne ve teşvik ödülüne ilişkin düzenlemelerin 6769 sayılı Kanun'la uyumu değerlendirilmektedir.

Anahtar Kelimeler: Çalışan Buluşu, Patent İsteme Hakkı, Bildirim Yükümlülüğü, Patent Bedeli, Teşvik Ödülü.

\begin{abstract}
Right to request a patent on an invention belongs to the inventor in principle. However, it is possible that the right to request a patent on an invention may be granted to another person by an act or absolute assignment of the right by the inventor. A uniform rule or principle has not been accepted in international law as to whether patent right of employees' invention belong to the employees or the employers. In Turkish patent law, employers have a formative right to choose the right to request a patent on an invention provided that some certain conditions are there. Accordingly, employees have an obligation to make a legal notice to employers without any delay in case of making an invention. Employers can use their formative rights within a specific time determined by the Law upon the fulfillment of the notice of the employees.

Should the employers obtain the right to request a patent, they are obliged to pay a certain amount remuneration to the employees. A number of principles are accepted regarding remuneration rights of employees' invention in Turkish Industrial Property Act No: 6769 of 2016. Thereafter, a number of detailed provisions are accepted with the Regulation No: 30195 of 29.09.2017, taking into account of the principles accepted by the Act. However, the Regulation entitle employees to demand encouragement award which is never mentioned in the Act No: 6769 of 2016.

In this article, the regulations of employees' inventions in Turkish patent law and the amendments accepted by the Act and the Regulation related to employees' inventions are examined. Besides, the compliance of the provisions with regard to ascertaining of remuneration rights, the obligation of notification and the encouragement award in the Regulation with the Act is analyzed.
\end{abstract}

Keywords: Employees’ invention, Right to Request a Patent, Obligation of Notification, Remuneration, Encouragement Award. 


\section{GíRiș}

Buluşlar üzerinde patent isteme hakkı, kural olarak buluşu gerçekleştiren kişiye aittir $^{1}$. Ancak buluş üzerindeki hakkın, kanunla buluş sahibi dışında bir kişiye tanınması veya buluş sahibi tarafından üçüncü kişilere devredilmesi mümkündür². Kanunlarla patent isteme hakkının buluş sahibinden başka bir kimseye tanınmasının çeşitli gerekçeleri bulunmaktadır. Bu gerekçelerden biri, hak tanınan kişinin buluşun gerçekleştirilmesi için ciddi yatırımlar yapması veya buluş sahibinin çalışmalarını sürdürmesi için gerekli ortamı tesis etmesidir ${ }^{3}$. Çalışan buluşları üzerinde işverene patent isteme hakkı tanınmasında, bu gerekçenin esaslı bir rolü bulunmaktadır.

Uluslararası hukukta, çalışanların gerçekleştirdiği buluşlar üzerinde patent isteme hakkının çalışana veya işverene ait olacağı konusunda bir düzenleme bulunmamaktadir ${ }^{4}$. Örneğin, fikri mülkiyet hukukunda yeknesak bir sistem oluşturmak isteyen Avrupa Birliği'nde dahi, işçi buluşlarında patent isteme hakkının kime ait olduğu, işçinin istihdam edildiği ülkenin hukukuna göre, bu tespit edilemiyorsa işverenin işyerinin bulun-

1 ÇELİK SİPAHİ, Özge, 551 Sayılı Kanun Hükmünde Kararname ile İşçi Buluşlarına İlişkin Patent Haklarının Korunması, Yayımlanmamış Yüksek Lisans Tezi, Ankara, Başkent Üniversitesi Sosyal Bilimler $\quad$ Enstitüsü, $\quad 2009, \quad$ s. https://angora.baskent.edu.tr/acik_arsiv/dosya_oku.php?psn=2409\&yn=382\&dn=1 (erişim tarihi: 15.09.2019). Buluşların ortaya çıkması, fikri bir çalışmayı gerektirdiği için ancak gerçek kişiler buluş sahibi olabilirler, ancak bu durum tüzel kişilerin patent hakkına sahip olmalarına engel değildir, bkz. ÇELİK, Aytekin, "Faydalı Model Belgelerinin Hükümsüzlüğü”, BATIDEER, Yıl: 2011, Cilt: 27, Say1: 1, s. 137; TEKİNALP, Ünal, "Yeni Patent Hukukunda "Buluş Sahibi İlkesi" ve Gasp Davalarına İlişkin Bazı Sorunlar", İHFM, Yı1: 1997, Cilt: 55, Sayı: 4, s. 130; SMK md. 112 gerekçesi, http://www2.tbmm.gov.tr/d26/1/1-0699.pdf (erişim tarihi: 15.09.2019).

2 KAYATEKİN, Deniz, Patentin Hükümsüzlüğü, On İki Levha Yayınları, İstanbul, 2013, s. 30; SARAÇ, Tahir, "551 Sayılı KHK'nin 11. Maddesine Göre Patent İsteme Hakkı ve Hakkın Sahibi”, Prof. Dr. Hayri DOMANİÇ’e 80. Yaş Günü Armağanı, (ed. KENDİGELEN, Abuzer), Cilt: 1, Beta Yayınları, İstanbul, 2001, s. 525.

3 GÜNEŞ, İlhami, Patent ve Faydalı Model Hukuku, Seçkin Yayıncılık, Ankara, 2017, s. 154; SULUK, Cahit / KARASU, Rauf / NAL, Temel, Fikri Mülkiyet Hukuku, 3. Baskı, Seçkin Yayıncılık, Ankara, 2019, s. 252; ÇATAKLAR, Eda, "Sınai Mülkiyet Kanunu ile Çalışanların Tasarımları ve Buluşları Üzerindeki Hak Sahipliği Sisteminde Yapılan Değişiklikler”, 6769 Sayılı Sınai Mülkiyet Kanunu Sempozyumu, (ed. ŞEHİRALİ ÇELIK, Feyzan Hayal), Bankacılık ve Ticaret H. Araş. E, Ankara, 2017, s. 409.

4 BAECHTOLD, Philippe / MiYAMOTO, Tomoko / HENNINGER, Thomas, "International Patent Law: Principles, Major Instruments and Institutional Aspects", International Intellectual Property A Handbook of Contemporary Research, (ed. GERVAIS, Daniel J), Elgar, Northampton, 2015, s. 56. Çeşitli ülkelerin mevzuatında konunun düzenleniş biçimi için ayrıca bkz. http://limegreenip.hoganlovells.com/article/117/patents-law-on-employees-inventions-china (erişim tarihi: 15.09.2019). 
duğu ülke hukukuna göre belirlenmektedir ${ }^{5}$. Bu hüküm doğrultusunda, Avrupa devletlerinin de çalışan buluşları konusunda birbirinden farklı düzenlemeler kabul ettikleri görülmektedir ${ }^{6}$.

Türk hukukunda çalışan buluşları üzerindeki hak sahipliği, mutlak olarak çalışana veya işverene tanınmamaktadır. 6769 sayılı Sınai Mülkiyet Kanunu'nda ${ }^{7}$ karma bir sistem kabul edilmektedir. Buna göre, belli şartların gerçekleşmesi üzerine çalışan buluşlarına ilişkin patent isteme hakkı işverene aittir. İşverenin patent isteme hakkını elde etmesi halinde, çalışana bir bedel ödeme yükümlülüğü doğmaktadır. Söz konusu bedelin belirlenmesine ilişkin SMK ve Çalışan Buluşlarına, Yükseköğretim Kurumlarında Gerçekleştirilen Buluşlara ve Kamu Destekli Projelerde Ortaya Çıkan Buluşlara Dair Yönetmelik’te $^{8}$ birtakım ilke ve esaslar öngörülmektedir.

\section{PATENT ISTEME HAKKI}

\section{A. Genel Olarak}

Buluş tek kişi tarafından gerçekleştirilirse, patent isteme hakkı buluş sahibine aittir. Buluşun birden çok kişi tarafından gerçekleşmesi, ortak buluş ${ }^{9}$ veya çifte buluş şeklinde ortaya çıkmaktadır. SMK md. 109/2 gereğince, ortak buluşlarda patent isteme

5 Avrupa Patent Sözleşmesi md. 60/1. Türkiye, Avrupa Patent Sözleşmesi’ni 07.06.2000 tarih ve 2000/842 sayılı Bakanlar Kurulu Kararıyla kabul etmiştir. Söz konusu Karar ile Sözleşme’nin Türkçe metnine ulaşmak için bkz. RG. 12.07.2000 (Mükerrer), Sayı: 24107.

6 AB ülkelerinde çalışan buluşlarına ilişkin yasal düzenlemeler hakkında detaylı bilgi için bkz. WOLK, Sanna, "Remuneration of Employee Inventors - Is There a Common European Ground? A Comparison of National Laws on Compensation of Inventors in Germany, France, Spain, Sweden and the United Kingdom”, IIC, Y1l: 2011, Cilt: 42, Say1: 3, s. 272 vd.; PEBERDY, Morag / STROWEL, Alain, "Employee's Rights to Compensation for Inventions - A European Perspective", Life Sciences, Y1l: 2009, Say1: 10, s. 63 vd., www.practicallaw.com/9-500-8968 (erişim tarihi: 15.09.2019).

7 RG. 10.01.2017, Sayı: 29944, (bundan sonra "SMK" olarak anılmaktadır).

8 RG. 29.09.2017, Sayı: 30195, (bundan sonra "Yönetmelik" olarak anılmaktadır).

9 Bir buluşun gerçekleşmesinde birden fazla kişi fikrî çalışmalarla katkıda bulunmuşsa, söz konusu buluş ortak buluş olarak tanımlanmaktadır. Ortak buluşlarda birden çok kişi aynı buluşu bir kere ve birlikte gerçekleştirirken; çifte buluşlarda aynı buluş, birbirinden habersiz kişiler tarafından birden fazla kez gerçekleştirilmektedir, bkz. ŞEHİRALİ ÇELIK, Feyzan Hayal, Patent Hakkının Korunması, Yayımlanmamış Yüksek Lisans Tezi, Ankara, Ankara Üniversitesi Sosyal Bilimler Enstitüsü, 1997, s. 57, https://tez.yok.gov.tr/UlusalTezMerkezi/tezSorguSonucYeni.jsp (erişim tarihi: 15.09.2019); KAYATEKİN, 2013, s. 30; SARAÇ, 2001, s. 532. 
hakkı buluşun gerçekleşmesinde fikri katkı sağlayan ${ }^{10}$ kişilerin tamamına aittir ${ }^{11}$. Ancak buluşu gerçekleştiren kişiler, sözleşme ile aksini kararlaştırabilmektedir.

SMK md. 109/3'e göre, çifte buluşlarda patent isteme hakk1, önceki başvurunun yayınlanmış olması şartıyla ${ }^{12}$ önceki başvuru sahibine aittir. Başka bir ifadeyle, birbirinden bağımsız olarak aynı buluşu gerçekleştiren kişilerden ilk başvuran kişi, patent isteme hakkını elde etmektedir. İlk başvuru sahibinin bu hakkı elde edebilmesi için, başvurusunun yayımlanmış olması gerekmektedir. Sonraki başvuru sahibinin patent

10 Ortak buluşlarda, bir kişinin patent isteme hakkına sahip olabilmesi için fikrî bir çabasının bulunması zorunludur. Ancak buluş sahiplerinin gösterdiği fikrî çabanın ve çalışmaların eşit oranda veya eşit nitelikte olması şart değildir. Tek başına sermaye veya malzeme tedariki, kişiye patent isteme hakkı tanımaz, bkz. KAYATEKİN, 2013, s. 30-31; SARAÇ, 2001, s. 533.

11 Ortak buluşun gerçekleşmesinde kişiler birlikte çalışmışlarsa, patent üzerindeki hak bakımından aralarındaki hukuki ilişkiye elbirliği mülkiyetine ilişkin hükümler uygulanır. Ancak kişilerin çalışmaları zamansal olarak farklıysa ve aralarında bir iş bölümü anlaşması yoksa aralarındaki ilişkiye paylı mülkiyet ve adi ortaklık hükümleri uygulanır, bkz. ŞEHİRALİ ÇELIK, 1997, s. 58; TEKİNALP, Ünal, Fikri Mülkiyet Hukuku, Vedat Kitapçılık, 5. Baskı, İstanbul, 2012, s. 558, Nr. 10.

12 Bu şart 6769 sayılı SMK ile kabul edilmiş olup 551 sayılı KHK'da yer almamaktaydı. SMK'de, önce başvuran kişinin patent başvurusu yayımlanmadan diğer bir kişi patent başvurusunda bulunduğunda, hangi başvuru sahibinin patent isteme hakkına sahip olduğu düzenlenmemiştir. O halde, ilk başvuru sahibinin patent başvurusu yayımlanmadan, başka bir kişi aynı buluş için patent başvurusunda bulunursa patent isteme hakkı hangi başvuru sahibine tanınacaktır? Böyle bir olasılıkta, önce başvuran kişi için patent işlemlerine devam edilmesi daha isabetli olacaktır. Sonra başvuran kişi, şayet buluşuna ilişkin ilk başvuran kişinin bir gasp fiili olduğunu iddia ediyorsa, patent isteme hakkının gaspı davası açmalıdır. Aksi halde patent isteme hakkı ilk başvuru sahibine ait olmalıdır. Çünkü SMK md. 83 ve md. 101'de, patent verilebilirlik şartları ve patent haklarının koruma süresinin belirlenmesi açısından patent başvuru tarihi esas alınmaktadır. Hal böyle iken, hak sahipliğinin belirlenmesinde, başvuru sahibinin elinde olmayan ve TÜRKPATENT'in yetkisinde bulunan bir işlemin esas alınmasının isabetli bir düzenleme olmadığı kanaatindeyiz.

SMK'de buluş sahibi ilkesinin benimsendiğinin iddia edilmesi halinde yukarıda ileri sürülen sorunun çözümü çok daha güç bir hale gelmektedir. Çünkü patent başvuru aşamasında, TÜRKPATENT nezdinde hak sahipliği iddiasında bulunulamamaktadır. Hak sahibi olduğunu iddia eden sonraki başvuru sahibi mahkemede gasp davası açabilir. Ancak gasp fiilinin unsurları gerçekleşmemişse, bu dava sonraki başvuru sahibine patent almak için bir çözüm yolu olmayacaktır. İkinci bir ihtimal, sonraki başvuru sahibinin buluşu daha önce gerçekleştirdiğinin tespiti için tespit davası açmasıdır. Ancak tespit davası bir eda hükmü içermediği ve SMK'de tespit ilamına dayanılarak başvuru sahibine bir yetki verilmediği için, sonraki başvuru sahibi TÜRKPATENT'ten buluşunun tescilini talep edemeyecektir. Bir an için böyle bir ihtimale gerçeklik tanındığında ise, TÜRKPATENT'in önceki başvuru sahibine patent vermesi halinde bir çözüm söz konusu olmayacaktır. Zira uluslararası araştırma ve inceleme otoriteleri tarafından hazırlanmış araştırma ve inceleme raporları sonucu patent almış ve patent için önce başvuruda bulunmuş kişiden, bir mahkemenin tespit hükmünü içeren ilamına dayanarak patentinin iadesini istemek hakkaniyete aykırı olacaktır. Bu nedenle, Türk hukukunda başvuru ilkesinin esas olduğunu kabul etmenin ve ilk başvuru sahibine patent isteme hakkını tanımanın daha isabetli olacağı kanaatindeyiz. 
isteme hakkına sahip olması ancak rüçhan hakkının bulunması halinde söz konusudur (SMK md. 93/7, 109/3 ve 155) ${ }^{13}$.

\section{B. Çalışan Buluşlarında}

SMK'de 551 sayılı KHK' deki işçi kavramından ${ }^{14}$ daha kapsayıcı olarak çalışan ifadesi kullanılmaktadır'15. SMK md. 2/(d)'ye göre çalışan “özel hukuk sözleşmesi veya benzeri bir hukuki ilişki gereğince, başkasının hizmetinde olan ve bu hizmet ilişkisini işverenin gösterdiği belli bir işle ilgili olarak kişisel bir bağımlılık içinde ona karşı yerine getirmekle yükümlü olan kişiler ile kamu görevlilerini” ifade etmektedir. Ayrıca SMK md. 113/3'e göre, stajyerler ve öğrenciler de çalışan buluşlarına ilişkin düzenlemelere tâbidirler.

SMK md. 113'te çalışan buluşları hizmet buluşu ve serbest buluş olarak iki sınıfa ayrılmaktadır. Hizmet buluşlarında buluşçu hakkı çalışana ait olmakla birlikte, SMK, işverenlere hizmet buluşları üzerindeki hakkı kısmen veya tamamen devralma imkânı sağlamaktadır ${ }^{16}$. Başka bir ifadeyle, hizmet buluşlarında işverene patent isteme hakkının

13 Kanunun gerekçesinde önceki başvurunun yayımlanmadan geri çekilmesi veya reddedilmesi halinde patent isteme hakkının sonraki başvuru sahibine ait olacağı ifade edilmektedir. Bu ifadenin sonraki başvuru sahibine yeni bir hak tanıdığını söylemek mümkün değildir. Zira SMK'de önceki başvuru sahibinin patent isteme hakkı, başvurusunun yayımlanmış olması şartına bağlanmıştır. Bu yüzden, başvuru yayımlanmadan geri çekilmişse veya reddedilmişse, önceki başvuru sahibinin kanundan doğan bir patent isteme hakkından bahsetmek mümkün olmayacaktır. Bu durumda, sonraki başvuru sahibinin patent isteme hakkı yeniden doğmayacaktır; başvuru hakkı, genel kurallar dâhilinde (SMK md.105/3) sonraki başvuru sahibine ait olacaktır.

14 Bir görüşe göre, 551 sayılı KHK’deki işçi kavramı geniş yorumlanmalıdır. İş kanununda tanımlanan işçi kavramı ve 551 sayılı KHK'de zikredilen stajyer ve öğrenciler ile sınırlı tutulmamalıdır. İşçinin hangi kanuna tâbi olduğunun veya iş yerindeki unvanının bir önemi bulunmamaktadır, bkz. ŞEHİRALİ ÇELIKK, 1997, s. 59; SARAÇ, Tahir, "Çalışanlar Tarafından Gerçekleştirilen Buluşlarda Patent Kime Verilecektir”, SDÜIİBFD, Y1l: 2004, Cilt: 9, Sayı: 2, s. 263-264; CANBOLAT, Talat, İşçi Buluşları, Beta Yayınları, İstanbul, 2007, s. 68, 96-97. Serbest çalışan, acente ve şirket ortağının işçi tanımının kapsamı dışında olduğu yönünde ayrıca bkz. SULUK / KARASU / NAL, 2019, s. 253.

15551 sayılı KHK'de çalışanların buluşları, işçilerin gerçekleştirdiği buluşlar ile kamu hizmeti gören kurumlarda çalışanların ve silahlı kuvvet mensuplarının gerçekleştirdiği buluşlar olmak üzere ayrı maddelerde düzenlenmişti. Ancak silahlı kuvvetler mensuplarının gerçekleştirdiği buluşlar için, memurların buluşlarına ilişkin 551 sayılı KHK md. 39'a; memurların gerçekleştirdikleri buluşlar için ise işçi buluşlarına ilişkin hükümlere atıf yapılmaktaydı. SMK'de böyle bir ayrıma yer verilmemiş, konu tek bir başlık altında düzenlenmiştir. SMK md. 113/4'e göre, çalışanların buluşuna ilişkin hükümler, diğer kanuni düzenlemeler ve taraflar arasında yapılan sözleşme hükümleri saklı kalmak kaydıyla kamu kurum ve kuruluşlarında çalışanların buluşları hakkında da uygulanmaktadır.

16 TEKINALP, 2012, s. 561, Nr. 19; YILDIZ, Şükrü: "551 Sayılı Patent Haklarının Korunmas1 Hakkında Kanun Hükmünde Kararname Hükümlerine Göre Üniversite Mensuplarının Buluşları”, AÜEHFD, Yıl: 2002, Cilt: 6, Say1: 1-4, s. 249; GÜNEŞ, İlhami, “Türk Patent Hukuku 
verilmesi, hakkın şarta bağlı olarak kanuni bir devridir ${ }^{17}$. Bu şart, işverenin çalışanın bildirimi üzerine tam hak sahipliğinde bulunduğuna ilişkin çalışana bildirimde bulunmasıdır. Serbest buluşlarda ise patent isteme hakkı çalışana aittir ${ }^{18}$. Çalışanın kanuni olarak buluşu devretmek gibi bir yükümlülüğü bulunmamaktadır. Hizmet buluşlarında olduğu gibi işverenin serbest buluşu tek taraflı bir irade açıklaması ile devralması söz konusu değildir ${ }^{19}$. Ancak işveren ile çalışan arasında buluş gerçekleştikten sonra patent hakkının kullanılmasına ilişkin sözleşme yapılması mümkündür ${ }^{20}$.

\section{Hak Sahipliğinin Belirlenmesinde Esas Alınan İki Ölçüt: Hizmet Buluşu ve Serbest Buluş}

\section{Hizmet Buluşunun Kapsamı}

Hizmet buluşu SMK md. 113/1'de tanımlanmaktadır. Buna göre, çalışanın bir işletme veya kamu idaresinde yükümlü olduğu faaliyeti gereği gerçekleştirdiği ya da büyük ölçüde işletme veya kamu idaresinin deneyim ve çalışmalarına dayanarak, iş ilişkisi sırasında yaptığ buluş, hizmet buluşudur. Hizmet buluşunun tanımında "iş ilişkisi”, “çalışanın yükümlü olduğu faaliyet alanı"21 ve "büyük ölçüde işletmenin veya kamu idaresinin deneyim ve çalışmalarından faydalanmak" ${ }^{22}$ unsurlarına yer verilmektedir. İş ilişkisi, hizmet buluşunun mutlak unsurudur. Diğer iki unsurdan birinin bulunması, buluşun hizmet buluşu olarak nitelendirilmesi için yeterlidir; bu nedenle söz konusu unsurlar alternatif niteliktedir.

SMK md. 113/1'e göre, hizmet buluşundaki mutlak unsur, buluşun çalışan ile işveren arasındaki iş ilişkisi devam ederken gerçekleştirilmesidir. İş ilişkisini mesai saat-

Uygulamasında İşçi (Hizmet) Buluşları, Serbest Buluş Kavramı ve Karşılaştırmalı Hukuk”, FMR, Y11: 2010, Cilt: 10, Say1: 2, s. 15.

17 CANBOLAT, 2007, s. 219.

18 ŞEHİRALİ ÇELİK, 1997, s. 60; TEKİNALP, 2012, s. 565, Nr. 36.

19 YILDIZ, 2002, s. 250.

20 Serbest buluşlarda çalışanın işverenle sözleşme kurma yükümlüğü için bkz. SMK md. 119/4.

$21 \mathrm{Bu}$ kapsamda gerçekleştirilen buluşlar, görevsel buluş olarak isimlendirilmektedir, bkz. ÇELIKK SİPAHİ, 2009, s. 70; ŞEHİRALİ ÇELIKK, 1997, s. 60.

22 Bu kapsamda gerçekleştirilen buluşlar, firsat buluşu olarak isimlendirilmektedir, bkz. ÇELIK SİPAHİ, 2009, s. 58; ŞEHİRALİ ÇELİK, 1997, s. 60. 
leri ile sınırlı kabul etmemek gerekir ${ }^{23}$. Çalışan ile işveren arasındaki sözleşme ilişkisi devam ediyorsa çalışanın izin dönemi veya mesai saatleri dışında buluşunu gerçekleştirmesi önem arz etmez ${ }^{24}$.

SMK'deki hizmet buluşuna ilişkin alternatif unsurlardan ilki, buluşun çalışanın yükümlü olduğu faaliyeti nedeniyle ortaya çıkmasıdır. Çalışanın yükümlü olduğu faaliyetin içeriği ve kapsamı, çalışan ile işveren arasındaki iş ilişkisine ve sözleşme hükümlerine bakılarak tespit edilir. Bu sebeple, buluşun iş görme borcundan kaynaklanıp kaynaklanmadığı tespit edilirken işçi ve işverenin tâbi olduğu kanun, sözleşme hükümleri ve iş yeri uygulamaları dikkate alınmalıdır ${ }^{25}$.

SMK'de hizmet buluşu tanımında öngörülen ikinci alternatif unsur, buluşun gerçekleşmesinde işletmenin veya kamu idaresinin deneyim ve çalışmalarının büyük ölçüde etkili olmasıdır. Buna göre, çalışanların görev alanı dışında gerçekleştirdiği buluşların hizmet buluşu sayılabilmesi için, işletmenin veya kamu idaresinin faaliyetlerinin ve deneyimlerinin buluşun gerçekleşmesinde büyük ölçüde etkili olması gerekmektedir ${ }^{26}$. İşletmenin veya kamu idaresinin basit bir katkısı yeterli değildir ${ }^{27}$. İşletmenin veya kamu idaresinin katkısının oranı tespit edilirken sermaye ve araç-gereçlerin kullanımının yanı sıra ${ }^{28}$; işletmenin faaliyet alanı, işçi ile işletme arasındaki ilişkinin niteliği, işletmeye ait know-how, işletmenin gerçekleştirdiği hukuki işlemlere ilişkin görüşmeler ve girişimler de dikkate alınır ${ }^{29}$.

23 ÇELİK SİPAHİ, 2009, s. 73; KÖSE, Mutlu Yıldırım, Patent ve Endüstriyel Tasarım Hukukunda Gasp Davaları, Yayımlanmamış Yüksek Lisans Tezi, İstanbul, İstanbul Üniversitesi Sosyal Bilimler Enstitüsü, 2010, s. 30, https://tez.yok.gov.tr/UlusalTezMerkezi/tezSorguSonucYeni.jsp (erişim tarihi: 15.09.2019); SARAÇ, 2004, s. 268.

24 CANBOLAT, 2007, s. 199; TEKİNALP, 2012, s. 561, Nr. 18; SULUK / KARASU / NAL, 2019, s. 254; NOYAN, Erdal, Patent Hukuku, 3. Bask1, Adalet Yayınevi, Ankara, 2015, s. 230.

25 CANBOLAT, 2007, s. 99; ÇATAKLAR, 2017, s. 424.

26 ÇATAKLAR, 2017, s. 425.

27 CANBOLAT, 2007, s. 125; ÖZ, Turgut, “Türk Patent Hukukunda Çalışanların Buluşları”, Prof. Dr. M. İlhan Ulusan'a Armağan, (ed. ALTOP, Atilla / WELSER, Rudolf / BELLICAN, Cüneyt/ URAL ÇINAR, Nihal / GÜMÜŞSOY KARAKURT, Güler), Cilt: 3, Seçkin Yayıncılık, Ankara, 2016, s. 594595. Çalışanın buluşu gerçekleştirirken yalnızca işletmenin deneyim ve çalışmalarından esinlenmiş olmasının buluşu hizmet buluşu haline getirmeyeceği yönündeki görüş için ayrıca bkz. ÇATAKLAR, 2017, s. 425.

28 GÜNEŞ, 2010, s. 15; TEKİNALP, 2012, s. 561, Nr. 16; SARAÇ, 2004, s. 268.

29 CANBOLAT, 2007, s. 126; ÇATAKLAR, 2017, s. 425. 
Büyük ölçüde işletmenin deneyim ve çalışmalarından yararlanma ölçütü, Yönetmelik'te sınırlandırılmıştır. Yönetmelik md. 4/1-(ç)'e göre, çalışanın buluşlarının hizmet buluşu sayılabilmesi için deneyim ve çalışmalarda "işletmenin faaliyet alanı" esas alınmaktadır. Buna göre, işveren işletmenin faaliyet alanı dışında gerçekleştirilen bir buluş üzerinde işletmenin deneyim ve çalışmalarının önemli bir katkısının olduğunu ileri süremez. Bu konuda örnek bir uyuşmazlık Almanya'da yaşanmıştır. Somut olayda uçaklarda kullanılmak üzere fiber malzemelerin üretildiği işyerinde çalışan bir kişi, işyerinin bu konudaki tecrübesinden faydalanarak rüzgâr sörfleri için yelken direği geliştirmiştir. Söz konusu buluş, çalışan tarafından mesai saatleri dışındaki çalışmalar sonucu ortaya çıkmış ve işyerinin faaliyet alanının dışında olsa da; buluşun gerçekleştirilmesi için işyerinin tecrübesinden faydalanıldığı için hizmet buluşu olduğu kabul edilmiştir ${ }^{30}$. Oysa söz konusu olayda, mevcut Türk hukuku kurallarının uygulanması halinde, çalışanın yararlandığı deneyim ve çalışmalar işletmenin faaliyet alanı dışında kaldığ için buluşun serbest buluş niteliğinde olduğunu kabul etmek gerekmektedir.

Buluşun hizmet buluşu niteliğinin belirlemesi bakımından hem çalışanın yükümlü olduğu faaliyet kriterini hem de işletmenin deneyim ve çalışmalarından yararlanma kriterini içeren örnek bir uyuşmazlık İngiltere'de yaşanmıştır. Somut olayda, bir mühendislik firmasında sübap satışından sorumlu bir çalışan, sübaplara ilişkin bir sorunun çözülmesini sağlayan bir buluş gerçekleştirmiş ve patentini istemiştir. İşveren, patent üzerinde hak sahipliği iddiasında bulunduğunda, mahkeme, çalışanın olağan görevleri arasında dizayn ve buluş yapmanın bulunmadığı, sadece satıştan sorumlu olduğu, işletmenin de buluş ile çözülen sorunun ortadan kalkması için bir amacı ve gayretinin bulunmadığı gerekçelerine dayanarak patent isteme hakkının çalışana ait olduğuna karar vermiştir. Kararda çalışanın olağan görevleri arasında dizayn ve buluş yapmanın bulunmadığının ve sadece satıştan sorumlu olduğunun belirtilmesi, buluşun çalışanın yükümlü olduğu faaliyetten kaynaklanmadığının gerekçesini oluşturmaktadır. İşletmenin, buluş ile çözülen sorunun ortadan kalkması için bir amacının ve gayretinin bulunmama-

30 ÇATAKLAR, 2017, s. 425-426. 
sı ile çalışanın işletmedeki görev pozisyonu da, çalışanın buluşunda işletmenin deneyim ve çalışmalarından yararlanmadığını göstermektedir ${ }^{31}$.

Hizmet buluşları açısından belirtilecek son bir husus, kamu görevlileri bakımından hizmet buluşuna ilişkin öngörülen kuralların uygulanmayabileceği ihtimalidir. Çünkü SMK md. 113/4'te, çalışan buluşlarına ilişkin düzenlemelerin mevzuatta var olan düzenlemeler ile sözleşme hükümleri dışında kamu kurum ve kuruluşlarında çalışanlar hakkında da uygulanacağı öngörülmektedir. Doktrinde bu hükümden yola çıkılarak, çalışanlar ile kamu kurumları arasında buluş konusunda çalışan buluşlarına ilişkin düzenlemelerden ayrılacak nitelikte sözleşmelerin yapılabileceği ileri sürülmektedir ${ }^{32}$. Örneğin, kamu kurum ve kuruluşları, kamu görevlileriyle yapacakları sözleşmelerle bu ölçütlerden bağımsız olarak buluşların hizmet buluşu veya serbest buluş olduklarını belirleyebilirler.

\section{Serbest Buluşun Kapsamı}

SMK'de serbest buluşların tanımına yer verilmemekte; hizmet buluşu dışında kalan çalışan buluşlarının serbest buluş olduğu kabul edilmektedir. Buna göre serbest buluş, çalışanın görevinden kaynaklanmayan ve işletmenin deneyim ve çalışmalarının buluşun ortaya çıkmasında esaslı bir katkısının olmadığı buluşlardır ${ }^{33}$. Bunun yanı sıra, SMK'de bazı durumlarda buluşun serbest buluş niteliğinde olduğu veya sonradan serbest buluş niteliği kazanacağı açıkça öngörülmektedir ${ }^{34}$.

31 Karar metni için bkz. https://www.gov.uk/guidance/manual-of-patent-practice-mopp/section-39-rightto-employees-inventions (erişim tarihi: 15.09.2019).

32 SULUK / KARASU / NAL, 2019, s. 257.

33 Çalışanın emeğinin ve bilgisinin yoğun olduğu bir buluş söz konusu ise serbest buluşun; işletmenin faaliyet ve deneyimlerinin yoğun olduğu bir buluş ise hizmet buluşunun varlığından söz edilir, bkz. CANBOLAT, 2007, s. 103; ÇELİK SİPAHİ, 2009, s. 72.

34 Bkz. SMK md. 115/1, md. 115/3, md. 116/4, md. 120. 


\section{II. ÇALIŞAN BULUŞLARININ PATENT BAŞVURU SÜRECİ}

\section{A. Çalışanın Bildirimde Bulunması}

\section{Genel Olarak}

SMK'ye göre, çalışan bir buluş gerçekleştirdiğinde ${ }^{35}$ bu durumu işverene bildirmekle yükümlüdür. Bildirim sayesinde, işveren buluşun varlığından haberdar olmakta ve hakkını kullanıp kullanmamak noktasında tercihte bulunabilmektedir ${ }^{36}$. Bildirim yükümlülüğü, iş ilişkisinden kaynaklı sadakat yükümlülüğünün bir yansıması olsa da, kanundan doğan bir borçtur ${ }^{37}$.

Çalışanın bildirim yükümlülüğü, buluşun tamamlandığı an ${ }^{38}$ doğmaktadır ${ }^{39}$. SMK md. 114/1 ve md. 119/1'e göre, çalışan gecikmeksizin bildirim yükümlülüğünü yerine getirmelidir. Bildirim yükümlülüğünün SMK'ye uygun bir zamanda yerine getirilip getirilmediği, somut olayın özellikleri ve çalışanla işveren arasındaki sadakat yükümlülüğünün niteliği dikkate alınarak belirlenmelidir ${ }^{40}$.

Buluşun izin, hastalık veya grev gibi zamanlarda gerçekleştirilmiş olması, çalışanın işverene karşı bildirim yükümlülüğünü ortadan kaldırmaz ${ }^{41}$. Buna karşılık iş ilişkisi devam ederken üzerinde çalışılan ancak iş ilişkisi sona erdikten sonra gerçekleştirilen buluşlar açısından çalışanın bildirim yükümlülüğünün bulunmadığı kanaatindeyiz ${ }^{42}$. Çünkü SMK'de, çalışanın bildirim yükümlülüğünün buluşun tamamlanmasından sonra doğacağı öngörülmektedir. Ayrıca, işverenin iş ilişkisinin sona ermesinden sonra, bulu-

35 Çalışanın bildirimi, gerçekleştirilen bir buluşa ilişkin olmalıdır. Bu nedenle, çalışanın belirli dönemlerde sunduğu faaliyet raporları veya yapılan deneylerin sonuçları, bir buluşun gerçekleştirilebileceğini içeren beyanlar içerse dahi çalışanın bildirim yükümlülüğünü ortadan kaldırmaz, bkz. CANBOLAT, 2007, s. 198, 203.

36 TEKİNALP, 2012, s. 562, Nr. 20.

37 CANBOLAT, 2007, s. 195.

38 Yükümlülüğün buluşun tamamlandığı an doğmasının dayanağı, SMK md. 114/1'deki "çallşan, bir hizmet buluşu yaptı̆̆ında" ifadesidir.

39 Test aşamalarının tamamlanmasını beklemiş olması, çalışanın bildirim yükümlülüğünü yerine getirmediği veya geç yerine getirdiği anlamına gelmez.

40 CANBOLAT, 2007, s. 195; ÇATAKLAR, 2017, s. 428.

41 CANBOLAT, 2007, s. 196.

42 Aksi yönde görüş için bkz. CANBOLAT, 2007, s. 199. 
şun ön çalışmalarına katılmış bir çalışana buluş için bedel ödeme yükümlülüğü öngörülmemişken, çalışana bildirim yükümlülüğünün getirilmesi uygun değildir.

SMK md. 114/1 ve Yönetmelik md. 5/1'e göre, buluşun birden çok çalışan tarafından gerçekleştirilmesi halinde, çalışanlar bildirim yükümlülüğünü birlikte yerine getirilebilmektedir. Ancak bildirimin çalışanlardan biri tarafından yapılması da mümkündür ${ }^{43}$.

Hizmet buluşlarında bildirim yükümlülüğü yazılı olarak yerine getirilmelidir ${ }^{44}$. Yazılılık şekli, geçerlilik şartı olarak kabul edilmekte ve bu şekilde yapılmayan bildirimin çalışanın yükümlülüğünü ortadan kaldırmadığı ileri sürülmektedir ${ }^{45}$.

Bildirim yükümlülüğünün geç yerine getirilmesi, çalışanın buluşu tamamlamış olmasına rağmen haklı bir neden olmaksızın işverene bildirimde bulunmamış olmasıdır ${ }^{46}$. Yönetmelik md. 5/7'ye göre, bildirim yükümlülüğünün geç yerine getirilmesi ${ }^{47}$ veya yerine getirilmemesi halinde çalışanın işverene karşı sorumluluğu doğmaktadır ${ }^{48}$. Ayrıca işveren, bildirim yükümlülüğünün yerine getirilmemesi halinde, aynen ifa talebiyle mahkemeye başvurabilmektedir. Bu durumda, mahkeme kararının gereği bildirim yerine geçmekte ve işveren buna göre SMK' den doğan haklarını kullanabilmektedir ${ }^{49}$.

43 Kanaatimizce çalışanlardan birinin bildirimde bulunması, diğer çalışanların bildirim yükümlülüklerini ortadan kaldırmaktadır. Aksi yönde görüş için bkz. ÖZ, 2016, s. 597.

44 Serbest buluşlar hakkında çalışanın bildirim yükümlülüğünün yazılı olmasına ilişkin bir ifade SMK ve Yönetmelik’te yer almamaktadır. Ancak SMK md. 119 düzenlemesi dikkate alındığında, işverenin buluşun serbest buluş niteliğe sahip olup olmadığını değerlendirebilmesi açısından bildirimin yazılı yapılması gerektiği kanaatindeyiz.

45 CANBOLAT, 2007, s. 199. Yazılılık şartının 1slak imzalı veya güvenli elektronik imzalı belge ile yerine getirileceği; iş yeri uygulaması haline dönüşmedikçe faks veya e-posta yoluyla yapılan bildirimlerin geçerli olmayacağı yönünde ayrıca bkz. CANBOLAT, 2007, s. 199-200.

46 CANBOLAT, 2007, s. 196.

47 Yönetmelik’te çalışanın bildirim yükümlülüğüne aykırı davranışı nedeniyle sorumluluğu yalnızca hizmet buluşları için öngörülmektedir. Kanaatimizce söz konusu sorumluluğun serbest buluşlar açısından da öngörülmesi daha isabetli olacaktır. Çünkü sorumluluk nedeniyle dava açılması halinde çalışan buluşun serbest buluş olduğu savunmasını yapabilir.

48 Çalışanın geç bildirimde bulunması veya bildirimde bulunmaması nedeniyle işverenin uğradığı zarara ilişkin SMK'de bir düzenleme bulunmamaktadır. Yönetmelik md. 5/7'deki hükmün SMK'de düzenlenmesi gerektiği yönündeki görüş için bkz. ÇATAKLAR, 2017, s. 428.

49 ÖZ, 2016, s. 596-597. 
Çalışanın bildirim yükümlülüğü, işverene ulaşması gereken bir bildirim olup bu yükümlülüğün yerine getirildiğinin ispatı, çalışana aittir ${ }^{50}$. Çalışan, işverenin bildirime ilişkin belirteceği usul ve esaslara uygun olarak, işverene veya işverenin yetkilendirdiği bir birime bildirimde bulunabilir. Buna göre, çalışanın bildiriminin muhatabı, öncelikle işverenin belirleyeceği usul ve esaslara göre belirlenmektedir. Yönetmelik md. 5/1'e göre, işverenin buluş bildirimlerinin yapılacağı bir birimi yetkilendirmediği durumlarda, çalışan bağlı olduğu birimin yetkilisine bildirimde bulunabilir ${ }^{51}$.

\section{Hizmet Buluşlarında}

Hizmet buluşlarına ilişkin çalışanın bildirim yükümlülüğü SMK md. 114'te düzenlenmektedir. SMK md. 114/2'ye göre, çalışan teknik problemi, bu problemin çözümünü ve buluşu nasıl gerçekleştirdiğini bildiriminde açıklamalıdır. Buluşun daha iyi açıklanmasını sağlayacaksa buluşa ilişkin resimlerin de bildirilmesi gerekmektedir ${ }^{52}$.

SMK md. 114/5 ve Yönetmelik md. 5/5'te, çalışanın bildirim yükümlülüğünü yerine getirebilmesi için işverene gerekli yardımda bulunma ödevi yüklenmiştir. Bu kapsamda, işverenin çalışan bildirimlerinin kabul edileceği bir birim oluşturması veya görevlendirmesi, bildirime ilişkin taslak form hazırlaması örnek gösterilebilir. Nitekim Yönetmelik md. 5/1'de işverenin çalışanın bildirim yükümlülüğüne ilişkin usul ve esaslar düzenleyebileceği, bildirimin yapılacağı bir birim oluşturabileceği öngörülmektedir.

İşveren, çalışanın bildirimi sonucunda buluş üzerinde doğacak haklarını tam olarak belirleyemiyorsa, bildirimin kanuna uygun olarak düzeltilmesini isteyebilir. Bildirim yükümlülüğünün eksik yerine getirildiğini iddia eden işverenin, eksik olan hususları açıç̧a belirtmelidir $^{53}$. Düzeltme talebi üzerine, çalışan Yönetmelik md. 5/5'e göre bir ay içerisinde ek bildirimde bulunmalıdır. Çalışanın yapacağı ek bildirim de ilk bildirim yükümlülüğünün tâbi olduğu usul ve şartlara göre yerine getirilmeli ve işverenin düzel-

50 Belirtmekte fayda var ki, işverenin çalışanın bildirim yükümlülüğünü yerine getirmediği iddiası incelenirken dürüstlük ve iyi niyet kuralları dikkate alınmalıdır. Ayrıntılı bilgi için bkz. CANBOLAT, 2007, s. 201-202.

$51 \mathrm{Bu}$ düzenleme, özellikle işveren ile çalışan arasında iletişim imkânının çok kısıtlı olduğu büyük işletmeler bakımından makul bir çözüm sağlamaktadır.

52 SMK'de belirtilen resim ifadesinin geniş yorumlanması, fiziki veya dijital çizimlerin de madde kapsamında değerlendirilmesi gerektiği kanaatindeyiz.

53 CANBOLAT, 2007, s. 206. 
tilmesini veya belirtilmesini istediği hususları içermelidir ${ }^{54}$. Çalışan bir ay içinde ek bildirimde bulunmazsa, bildirim yükümlülüğünü yerine getirmemiş sayılır. Bu halde, çalışan yeniden bildirimde bulunmalıdır. Buna karş1lık, SMK md. 114/4'e göre, işveren, bildirimden itibaren iki ay içinde düzeltme talebinde bulunmazsa, çalışanın bildirimi geçerli ve yeterli kabul edilmektedir ${ }^{55}$.

\section{Serbest Buluşlarda}

Serbest buluşlara ilişkin çalışanın bildirim yükümlülüğü SMK md. 119'da düzenlenmektedir. SMK md. 119/1'e göre, çalışan buluşunun serbest buluş olduğu konusunda işverenin kanaat edinmesini sağlayacak şekilde buluşu hakkında bildirimde bulunmalıdır. Bildirim, buluşun serbest buluş niteliğinde olup olmadığına ilişkin işverenin kanaat getirmesini sağlayacak gerekli açıklamaları içermelidir ${ }^{56}$. Örneğin, işveren için buluşun serbest buluş niteliğinde olup olmadığı açısından gerekliyse, buluşun gerçekleşme şekli de bildirimde açıklanmalıdır.

Çalışana serbest buluşu için bildirim yükümlülüğü getirilmesi, çalışanın yanılarak veya kasıtlı olarak hizmet buluşunu serbest buluş olarak nitelendirmesini engellemekte; işverene buluşun niteliğini araştırma ve itiraz etme imkânı sağlamaktadır ${ }^{57}$. SMK md. 119/2'ye göre, işveren çalışanın serbest buluş bildirimine üç ay içinde yazılı olarak itiraz edebilmektedir ${ }^{58}$. Öğretide, SMK md. 119/2'deki sürenin hak düşürücü süre olduğu; itiraz süresi geçtikten sonra işverenin itiraz hakkının bulunmadığı ileri sürülmektedir ${ }^{59}$.

54 CANBOLAT, 2007, s. 206.

55 SMK md. 114/4'te, yalnızca SMK md. 114/2'de belirtilen bildirimin geçerli olacağ düzenlenmektedir. Hâlbuki SMK md. 114/3'te çalışanın yararlanmış olduğu işletmenin deneyim ve çalışmalarını, varsa diğer çalışanların katkılarını ve bu katkıların şeklini, yaptı̆̆ı işle ilgili olarak aldığı talimatları ve söz konusu katkılar yanında kendisinin katkı payını da belirtmesi gerektiği düzenlenmektedir. Bu nedenle, çalışanın SMK md. 114/3'te yer alan hususlara bildiriminde yer vermemesi ve işverenin düzeltme talebinde bulunmamasının sonucu öngörülmemiştir. SMK md. 114/4'ün amaçsal yorumundan SMK md. 114/3'te yer alan eksiklikler hususunda da işverenin düzeltme talep etmemesi halinde yapılan bildirimin geçerli olduğunun kabulü gerekecektir. Aynı yönde görüş için bkz. CANBOLAT, 2007, s. 207.

56 ÇATAKLAR, 2017, s. 426.

57 ÇELİK SİPAHİ, 2009, s. 99; SARAÇ, 2004, s. 274; CANBOLAT, 2007, s. 196. Serbest buluşlarda çalışanın bildirim yükümlülüğünün bulunması, taraflar arasında doğabilecek gasp davalarını da önlemeye katkı sağlamaktadır.

58551 sayılı KHK md. 31/2'de, bu süre içerisinde işverenin itiraz etmemesi halinde, işverenin buluşun hizmet buluşu olduğunu ileri süremeyeceği öngörülmüştür. Ancak bu yönde bir düzenlemeye SMK'de 


\section{B. İşverenin Hak Sahipliğine İlişskin Kararı}

\section{Genel Olarak}

SMK md. 115/1'e göre, işveren buluş üzerinde tam veya kısmi hak talebinde bulunabilmektedir. İşverene tanınan hakkın niteliği, yenilik doğurucu bir haktır ${ }^{60}$. İşverenin beyanından hak talebinde bulunduğu anlaşılmakla birlikte tam hak sahipliği veya kısmi hak talebinde bulunduğu anlaşılmıyorsa tam hak sahipliği talebinde bulunduğu kabul edilmelidir ${ }^{61}$. İşveren buluşa ilişkin hak talebini yazılı olarak bildirmelidir. Öğretide, yazılılık şartının geçerlilik şartı olduğu ve bu konuda tarafların aksini kararlaştırmalarının mümkün olmadığı ileri sürülmektedir ${ }^{62}$.

İşveren tam hak sahipliği talebini çalışanın bildiriminden itibaren ${ }^{63}$ dört ay içinde çalışana bildirmelidir. Bu süre, hak düşürücü niteliktedir ${ }^{64}$. İşveren, söz konusu süre içinde buluşa ilişkin tam hak sahipliği talebinde bulunmazsa, buluş, serbest buluş niteliği kazanır. Bu durumda, patent isteme hakkı çalışana aittir ${ }^{65}$.

yer verilmemektedir.

59 ÇATAKLAR, 2017, s. 427.

60 CANBOLAT, 2007, s. 212, 219.

61 CANBOLAT, 2007, s. 229.

62 CANBOLAT, 2007, s. 217; ÇELIK SİPAHİ, 2009, s. 81; BAYRAKTAR, Servi, İşci Buluşları, Yayımlanmamış Yüksek Lisans Tezi, Ankara, Gazi Üniversitesi Sosyal Bilimler Enstitüsü, 2013, s. 90, https://tez.yok.gov.tr/UlusalTezMerkezi/tarama.jsp (erişim tarihi: 15.09.2019).

63 Hak düşürücü sürenin başlaması için çalışan, usulüne uygun olarak bildirimde bulunmalıdır. Bildirimin eksik yapılması ve işverenin düzeltme talebinde bulunması halinde, hak düşürücü süre, düzeltme talebi üzerine çalışanın son bildirimde bulunduğu tarihte işlemeye başlar. Çünkü işveren buluş üzerine hak sahipliğinde bulunup bulunmayacağı konusunda kanaat getirmesi için yeterli bilgilere düzeltme bildirimi ile sahip olmaktadır. Bildirimin SMK'de yer alan konulara göre eksik olmasına rağmen işverenin düzeltme talebinde bulunmaması halinde ise süre, bildirimin işverene ulaştığı tarihte başlar, bkz. CANBOLAT, 2007, s. 208.

Buluşu birden çok çalışanın gerçekleştirmesi ve çalışanların ayrı ayrı bildirimde bulunması halinde, işveren için hak sahipliği konusunda tanınan sürenin, her bir bildirim ve çalışan yönünden ayrı ayrı dikkate alınması gerektiği yönündeki görüş için ayrıca bkz. CANBOLAT, 2007, s. 214.

${ }^{64}$ GÜNEŞ, 2017, s. 157; CANBOLAT, 2007, s. 212; ÖZ, 2016, s. 596.

65 ŞEHIRALİ ÇELIK, 1997, s. 61. Öğretide, 2009 yllında Almanya'nın bu düzenlemeyi terk ettiği, işverenin açıkça reddetmemesi halinde buluşun işverene ait olacağının düzenlendiği, Almanya'daki düzenlemenin daha uygun olduğu ileri sürülmektedir, bkz. ÇATAKLAR, 2017, s. 429. Ancak, hak sahipliğine ilişkin buluş sahibi ilkesi dikkate alındığında ve işverene sağlanan hak sahipliği imkânının istisnai bir düzenleme olduğu düşünüldüğünde, Türk Hukukundaki düzenlemenin patent hukukunun asli amacına daha uygun olduğunu kabul etmek gerekir. Ayrıca, SMK md. 116/2'de hizmet buluşlarının serbest buluş haline gelebileceğinin öngörülmesi de, bu görüşü desteklemektedir. 


\section{2. İşverenin Tam Hak Sahipliği Talebinde Bulunması Halinde}

SMK md. 115/2'ye göre, işverenin buluş üzerinde tam hak talebinde bulunduğunu çalışana bildirdiği an, buluş üzerindeki tüm mali haklar işverene geçmektedir. SMK md. $115 / 2$ 'de işverene geçen hakların maddi veya manevi nitelikte olduğu belirtilmemiştir. Ancak SMK md. 90/6'ya göre, buluş sahibi, patent isteme hakkına sahip olan kişiden buluşu gerçekleştiren kişi olduğunun belirtilmesini isteme hakkına sahiptir. Bu nedenle, SMK md. 115/2'de buluş üzerindeki tüm hakların işverene geçeceği öngörülmüş olsa da, çalışanın başvuruda buluşu yapan olarak belirtilmesini isteme hakkının devam ettiği kanaatindeyiz ${ }^{66}$.

SMK md. 115/4'e göre, işverenin tam hak sahipliği talebinde bulunabilmesi için öngörülen süre içinde çalışanın buluş üzerine yaptığg tasarruflar, işverenin hakkını ihlal ettiği ölçüde, işverene karşı geçersizdir. Bu nedenle, çalışanın SMK md. 115/1'de öngörülen süre içinde buluş üzerindeki haklarını üçüncü bir kişiye devretmesi veya üçüncü kişiler lehine işverenin menfaatini zedeleyecek nitelikte haklar tanıması, işverene karşı ileri sürülemez. SMK md. 115/4'e göre, üçüncü kişilerin işverene karşı bu hususta iyiniyet iddiasında bulunması mümkün değildir.

\section{3. İşverenin Kısmi Hak Talebinde Bulunması Halinde}

İşveren, kendisi için patent üzerinde tam hak talebinde bulunmanın faydalı olmayacağını düşünebilir. Bu durumda patent üzerinde kendisine kısmi bir hak tanınmasını isteyebilir. İşverenin bu durumda elde ettiği hak, basit lisans niteliğindedir. İşverenin kısmi hak talebinde bulunması halinde, patent isteme hakkı, çalışana aittir ${ }^{67}$.

SMK md. 115/3'e göre, işverenin kısmi hak talebi çalışanın buluşu değerlendirmesini önemli ölçüde güçleştirmekteyse, çalışan, işverenden buluşa ilişkin hakların tamamını devralmasını veya buluş üzerindeki hakkından vazgeçmesini talep edebilmektedir. Çalışanın bu yönde talepte bulunması halinde, işveren talep tarihinden itibaren iki ay içinde ya buluşa ilişkin hakları devralacağını veya buluş üzerindeki kullanma hak-

66 Aynı yönde bkz. KÜÇÜKALİ, Canan, "Karşılaştırmalı Hukuk ve Türk Hukukunda Çalışanların Buluşları ve Patentlenmesi”, Terazi Hukuk Dergisi, Y11: 2019, Cilt: 14, Sayı: 152, s. 770; SARI, Onur, Patent Lisans Sözleşmeleri, Seçkin Yayıncılık, Ankara, 2019, s. 111.

67 KÖSE, 2010, s. 32; TEKİNALP, 2012, s. 561, Nr. 19. 
kından vazgeçtiğgini çalışana bildirmelidir ${ }^{68}$. İşverenin çalışanın talebine cevap vermemesi durumunda kısmi hak talebi sona ermektedir.

\section{Tam Hak Sahipliği Halinde İşverenin Patent Başvurusunda Bulunması}

SMK md. 116/1'e göre, işveren tam hak sahipliği talebinde bulunursa, buluş için patent başvurusunda bulunma hakkına ve yükümlülügüne sahiptir ${ }^{69}$. SMK'de işverenin patent başvurusunda bulunması için bir süre sınırı öngörülmemiştir ${ }^{70}$. Bunun yerine, SMK md. 116/4'te çalışana bir yetki verilmektedir. Buna göre, çalışan işverene patent başvurusunda bulunması için bir süre sınırı getirebilmektedir. Bu süre içinde işveren, SMK md. 116/2'ye göre, başvuru yükümlülüğü ortadan kalkmadığı halde başvuruda bulunmazsa; buluş, serbest buluş niteliği kazanır ${ }^{71}$.

Kural işverenin patent başvurusunda bulunması olmakla birlikte bazı hallerde işveren, başvuruda bulunma yükümlülüğ̈̈nden muaf tutulmaktadır. SMK md. 116/2'ye göre, çalışanın rızasının bulunduğu, buluşun daha sonra serbest buluş haline geldiği veya işletme sırlarının patent başvurusu yapılmamasını gerektirdiği durumlarda işverenin patent başvurusunda bulunma yükümlülüğü ortadan kalkmaktadır. Ayrıca SMK md. 116/1'e göre, işletme menfaatinin gerektirdiği durumlarda da işveren, patent başvurusu yapmaktan kaçınabilmektedir. SMK md. 116/1'deki işletme menfaatine dayanan muafiyet, SMK md. 116/2'deki işletme sırrına dayanan muafiyeti kapsayan bir niteliktedir. Bununla birlikte, işletme menfaati kavramı dar yorumlanmalıdır.

68 Hakkın sona erdirilmesi veya buluşa ilişkin hakların devralınması, SMK md. 115/3'te öngörülen iki aylık süre içinde gerçekleşmek zorunda değildir. Bu konuda SMK bir süre sınırı getirmemektedir. Ancak 4721 sayılı TMK md. 2 gereği, gerek kullanma hakkından vazgeçilmesi gerekse buluş üzerindeki hakların devralınması hayatın olağan akışında kabul edilebilecek bir zaman diliminde gerçekleşmelidir, 4721 sayılı Kanun metni için bkz. RG. 08.12.2001, Say1: 24607.

69 Kanaatimizce, işverenin başvuruda bulunma yükümlülüğü, başvurunun TÜRKPATENT tarafindan reddedilmesi halinde, karara karşı yargı yoluna başvurulmasını da beraberinde getirir. Çünkü çalışanın buluş için patent verilmesinde hem maddi hem manevi menfaati bulunmaktadır.

70 Hâlbuki Alman Çalışan Buluşları Hakkında Kanun'da bu konuda bir düzenlemeye yer verilmiştir. Alman Çalışan Buluşları Hakkında Kanun'un md. 13/1'de, işverenin gecikmeksizin başvuruyu yapma yükümlülüğü olduğu belirtilmektedir. Kanun metnine ulaşmak için bkz. Germany Act on Employees' Inventions/ Gesetz über Arbeitnehmererfindungen, http://www.wipo.int/wipolex/en/details.jsp?id=1004 (erişim tarihi: 15.09.2019).

71 Bu düzenleme, ilk defa SMK ile kabul edilmiştir. Konuya ilişkin mülga 551 sayılı KHK md. 26'da işverenin patent başvurusunda bulunmadığı durumlarda çalışanın işverenin ad ve hesabına başvuruda bulunabileceği düzenlenmekteydi. 
Patent başvurusunda bulunmamanın işletme sırrına veya işletme menfaatine dayanması halinde, bu durumun nasıl tespit edileceği mevzuatta öngörülmemektedir. Kanaatimizce, patent başvurusunda bulunmamanın işletme menfaatine veya işletme sırlarına uygun olduğu işverenin sübjektif değerlendirmesinden bağımsız, objektif olarak tespit edilebilmelidir.

Hizmet buluşlarının yurtdışında korunması için başvuru hakkı, aksi kararlaştırılabilir olmakla birlikte işverene aittir ${ }^{72}$. Bir başka ifadeyle, işverenin yurt dışında da hizmet buluşu için patent başvurusunda bulunma hakkı vardır; ancak yurt dışında patent alınması işveren için bir yükümlülük değildir ${ }^{73}$. Ancak işveren, yurt dışında patent başvurusunda bulunmazsa, başvuru hakkını çalışana devretmek zorundadır ${ }^{74}$.

\section{III. ÇALIŞAN BULUŞLARINDA ÇALIŞANIN BEDEL İSTEME HAKKI}

\section{A. Genel Olarak}

Çalışanın talep edileceği bedel konusunda 551 sayılı KHK'de, "uygun bedel” ifadesine yer verilirken, SMK'de "makul bedel” ifadesine yer verilmektedir. Doktrinde, düzenlemelerin içeriği ve niteliğinin benzer olması nedeniyle, bu kavram farklılığının bir değişikliğe yol açmadığı ileri sürülmektedir ${ }^{75}$.

SMK md. 115/9 ile Yönetmelik md. 11/1'e göre, çalişana ödenecek bedel ve bu bedelin ödenme şekli, taraflar arasında yapılacak sözleşme veya benzeri hukuki işlemlerle belirlenebilmektedir. Ayrıca Yönetmelik md. 25/1'e göre, bedele ilişkin konularda mevzuattaki standartlardan daha yüksek olması halinde, işyeri uygulaması esas alınmaktadır. Bu hüküm nedeniyle, Yönetmelik’teki bedele ilişkin düzenlemelerin, çalışana ödenecek bedel konusunda asgari bir standart oluşturduğu yorumu yapılmaktadır ${ }^{76}$.

72 GÜNEŞ, 2010, s. 16.

73 KÖSE, 2010, s. 32.

74 TEKINALP, 2012, s. 564, Nr. 30.

75 ÇATAKLAR, 2017, s. 430.

76 ÇATAKLAR, 2017, s. 432. 
551 sayılı KHK md. 25/1'e göre, çalışana ödenecek bedel belirlenirken yönetmelikteki hükümler dikkate alınmak zorundaydı. Buna karşılık, SMK'de bedel ve ödeme şekline ilişkin konularda tarafların Yönetmelik hükümlerini dikkate almaları gerektiği açıkça belirtilmemektedir ${ }^{77}$. Ancak Yönetmelik md. 25/1'de çalışanlarla ilgili hükümlerin nispi emredici hüküm niteliğinde olduğ ${ }^{78}$ ve çalışan aleyhine değiştirilemeyeceği açıkça düzenlenmektedir. Bu nedenle, doktrinde, hakkaniyete aykırılık oluşturması bakımından Yönetmelik'teki bedele ilişkin hükümlerin esas alınacağı; tarafların sözleşmede bedele ilişkin Yönetmelik hükümlerini göz önünde bulundurması gerektiği ifade edilmektedir ${ }^{79}$.

551 sayılı KHK md. 33 'te düzenlenen teknik iyileştirme tekliflerine ${ }^{80}$ SMK' de yer verilmemiştir. Bu nedenle, doktrinde artık işverenlerin teknik iyileştirme teklifleri nedeniyle ücret ödeme yükümlülüğünün bulunmadığı ileri sürülmektedir ${ }^{81}$. Buna karşılık, Yönetmelik md. 7/2'de işverenin tam hak sahipliği talebinde bulunması halinde çalışana teşvik ödülü ödeyeceği öngörülmektedir.

\section{B. Teşvik Ödülü}

\section{Teşvik Ödülünün Niteliği}

Yönetmelik md. 4/I'da, teşvik ödülü “işverenin tam hak sahipliği talep etmesi durumunda, çalışana buluşu hakkında yapılacak başvuru karşılığında verilen meblağ" olarak tanımlanmaktadır. Yönetmelik md. 7/2'ye göre, teşvik ödülü çalışanın talep edeceği bedel hakkından bağımsızdır. İşverene bu yönde bir yükümlülük getirilmesinin hukuki dayanağı, işverenin çalışan buluşu için patent başvurusunda bulunmasıdır. Doktrinde teşvik ödülünün bir külfet olduğu ileri sürülmektedir ${ }^{82}$. Ancak külfetin tanımı dik-

77 ÇATAKLAR, 2017, s. 431.

78 CANBOLAT, 2007, s. 198.

79 ÇATAKLAR, 2017, s. 432.

80 Teknik iyileştirme teklifi, patent veya faydalı model belgesi ile korunamayacak nitelikte olan (551 sayılı KHK md. 16/2) buluşun niteliğine yönelik olumlu etki doğuracak yenilik ve gelişmelerdir.

81 ÇATAKLAR, 2017, s. 424.

82 ÇATAKLAR, 2017, s. 433. 
kate alındığında ${ }^{83}$, teşvik ödülü ödemesi işverene bir fayda sağlamadığı için, teşvik ödülünün külfet niteliğinde olduğunu söylemek isabetli olmayacaktır. Teşvik ödülü, taraflar arasındaki hukuki ilişki nedeniyle Yönetmelik ile işverene getirilmiş bir borçtur.

Yönetmelik md. 7/2'de, teşvik ödülüne ilişsin bazı hususlar öngörülmektedir. Buna göre, kamu kurum ve kuruluşlarında çalışanlar teşvik ödülü talep edemezler. Bu nedenle, buluş gerçekleştiren her çalışan, teşvik ödülü talep etme hakkına sahip değildir. İşverenin ödeyeceği teşvik ödülü net asgari ücret miktarından az olamaz. Buluş birden fazla çalışan tarafından gerçekleştirilmişse, teşvik ödülü, çalışanların buluş üzerindeki katkı payları oranında paylaştırılır. İşveren, teşvik ödülünü, TÜRKPATENT'in kendisine Sınai Mülkiyet Kanununun Uygulanmasına Dair Yönetmelik ${ }^{84}$ md. 96/3'e göre patent başvurusu hakkında şekli uygunluk bildiriminde bulunmasından itibaren iki ay içinde ödemekle yükümlüdür.

Teşvik ödülünün diğer ulusal düzenlemelerde de yer aldığı görülmektedir. Örneğin, Çin Halk Cumhuriyeti Patent Kanunu md. $16^{85}$ ve bu Kanuna dayanılarak hazırlanan 15.06.2001 tarih ve 306 sayılı Çin Halk Cumhuriyeti Patent Kanunu Yönetmeliği md. 77'de, çalışanın her bir buluş için işverenden bedel talebinin yanı sıra ödül/teşvik talebinde bulunabileceği ve bu ödül talebinin asgari miktarı düzenlenmektedir ${ }^{86}$. Mevcut yasaya göre, çalışan her bir buluş için yerel para birimi ile 3,000 RMB talep edebilmektedir ${ }^{87}$.

83 Külfet, bir kişinin diğer kişilere karşı belirli bir hakkı elde edebilmesi için yerine getirmekle yükümlü olduğu davranıştır. Kişi, bu yükümlülüğü yerine getirmediği takdirde, söz konusu hakkı kazanamaz veya kaybeder. Ancak, külfetin konusu olan davranışın yerine getirilmesi, hakkın muhatabı olduğu kişi veya kişiler tarafından talep edilemez. Külfet konusu davranış yerine getirilmediği için, hakkını kaybeden kişiye karşı külfetin ifası veya tazminat talebinde bulunulamaz. Ayrıntılı bilgi için bkz. EREN, Fikret, Borçlar Hukuku Genel Hükümler, 23. Baskı, Yetkin Yayınları, Ankara, 2018, s. 45; KILIÇOĞLU, Ahmet M., Borçlar Hukuku Genel Hükümler, 22. Baskı, Turhan Yayınları, Ankara, 2018, s. 45-46.

84 RG. 27.04.2017, Say1: 30047.

85 12.03.1984 tarihli Kanun metni için bkz. http://www.wipo.int/wipolex/en/text.jsp?file_id=178664 (erişim tarihi: 15.09.2019).

86 15.06.2001 tarih ve 306 sayılı Yönetmelik metni için bkz. http://www.wipo.int/edocs/lexdocs/laws/en/cn/cn078en.pdf (erişim tarihi: 15.09.2019).

87 FENG, Charles, China: Employee Inventions In China, http://www.mondaq.com/china/x/462864/Patent/Employee+Inventions+in+China (erişim tarihi: 15.09.2019). 


\section{Değerlendirmemiz}

Teşvik ödülüne ilişkin Yönetmelik’teki düzenleme, bazı açılardan ihtilafların çıkmasına neden olabilir. Öncelikle, SMK'de işverenin teşvik ödülü ödeyeceğine ilişkin bir düzenleme bulunmamaktadır. Hâlbuki teşvik ödülü, Yönetmelik’te işveren tarafından "ödenir" denilerek ve asgari sınırlar çizilerek zorunlu tutulmaktadır. Teşvik ödülünün SMK'de yer almamasına rağmen Yönetmelik'te düzenlenmiş olması, gerekli yasal zemine sahip olmadığı anlamına gelmektedir. Zira kanunda düzenlenmesi konusunda dayanağı olmayan bir konunun yönetmelikle öngörülmesi, idari işlemi sebep unsuru bakımından hukuka aykırı hale getirmektedir. Bu durum ise, yönetmelik hükümlerinin iptal edilmesi sonucunu doğurabilir. Bu nedenle, Yönetmelik’te teşvik ödülüne yer verilmesi, sosyal bir gereklilik veya ihtiyaçtan kaynaklanmaktaysa, bu ihtiyacın kanun ile güvence altına alınması daha isabetli olacaktır ${ }^{88}$.

Teşvik ödülüne ilişkin düzenleme, düzenlemenin zaman bakımından uygulanması konusunda eleştirilebilmektedir. Yönetmelik, 29.09.2017 tarihinde Resmi Gazetede yayımlanmış ve Yönetmelik md. 42 gereği yayım tarihinde yürürlüğe girmiştir. Bu nedenle, SMK'nin yürürlüğe girdiği 10.01.2017 tarihiyle Yönetmeliğin yürürlüğe girdiği 29.09.2017 tarihi arasında gerçekleştirilen ve işverene bildirilen hizmet buluşları bakımından işverenin teşvik ödülü ödeme yükümlülüğü bulunmamaktadır. Bu durum, aynı kanunun yürürlükte olduğu dönemde, işverenlerin aynı niteliğe sahip bazı buluşlar bakımından teşvik ödülü ödemesinin zorunlu olduğu; bazı buluşlar bakımından ise zorunlu olmadığı bir uygulamaya sebep olmaktadır.

İşverenin teşvik ödülünü ödemesi gereken zaman dilimi, uygulamada sorunlara neden olabilmektedir. Düzenlemeye göre, işveren, patent başvurusunda bulunması ve TÜRKPATENT'in kendisine Sinai Mülkiyet Kanununun Uygulanmasına Dair Yönetmelik md. 96/3'e göre başvuru hakkında şekli uygunluk bildiriminde bulunmasından itibaren iki ay içinde teşvik ödülünü ödemelidir. Oysa SMK md. 116/2'ye göre işveren,

88 Teşvik ödülünün Kanun ile düzenlenmesi ve bu borcun işverenin bedel ödeme yükümlülüğünden bağımsız olduğunun kanun ile öngörülmesi, teşvik ödülüne ilişkin uygulamanın da çalışan lehine oluşmasını sağlayacaktır. Zira düzenlemenin mevcut halinde, işverenin, teşvik ödülünü çalışan ile yapacağı sözleşmede bedelin kararlaştırılması aşamasında dikkate alması mümkündür. Başka bir ifadeyle, işveren zorunlu olarak ödediği teşviki tabii olarak buluş için bedelin belirlenmesi aşamasında dikkate almak isteyecektir. 
çalışanın rıza göstermesi ve işletme sırlarının korunmasının başvuru yapmamayı gerektirmesi durumlarında buluş üzerinde hak sahibi olsa da patent başvurusu yapmakla yükümlü değildir. Bu durumda, işveren başvuru yapmakla yükümlü olmadığı için teşvik ödülünün ödenmesi bakımından ifa zamanı başlamayacaktır.

Teşvik ödülüne ilişkin düzenlemedeki bir diğer sorun, düzenlemede kullanılan ifadeden kaynaklanmaktadır. Uygulama bakımından bir farklılığa neden olmamakla birlikte, Yönetmelik md. 7/2'deki “Buluş, birden çok çalışan tarafindan gerçekleştirilmişse teşvik ödülü buluşu yapanlar arasında katkı payları oranında bölüştürülür.” ifadenin "Buluş, birden çok çalışan tarafından gerçekleştirilmişse teşvik ödülü, çalışanlara buluşun gerçekleştirilmesindeki katkı payları oranında ödenir." şeklinde düzeltilmesi, düzenlemenin daha hukuki bir ifadeye sahip olmasını sağlayacaktır.

Teşvik ödülüne ilişkin düzenlemede, kamu kurum ve kuruluşlarında çalışanlar hakkındaki hüküm üzerinde durulabilir. Yönetmelik md. 7/2'de kamu kurum ve kuruluşlarında çalışanların teşvik ödülü talep edemeyeceği öngörülmektedir. Bu düzenleme, çalışanlar arasında farklı uygulamaya neden olacak bir kural öngörüldüğü için eleştiriye açıktır. Zira teşvik ödülünün niteliği dikkate alındığında, kamu kurumlarında çalışanlar ile özel sektörde çalışanlar arasında bir ayrımın yapılmaması gerektiği ileri sürülebilir. Bu nedenle, Yönetmelik’te yer alan bu hükmün SMK md. 113/4 kapsamında olup olmadığ incelenmelidir. SMK md. 113/4'te çalışan buluşlarına ilişkin düzenlemelerin kamu kurum ve kuruluşlarında çalışanlar için de uygulanacağı öngörülmektedir. Ancak SMK md. 113/4'te, kamu kurumlarının çalışanlarla yapacakları sözleşmeler ile kanuni düzenlemelerin öncelikle uygulanacağı da öngörülmüştür. SMK'de kanuni düzenlemeler ifadesine yer verildiği için kanunun yanı sıra alt düzenlemelerle de kamu kurumlarında çalışanlar için farklı düzenlemelerin öngörülmesi mümkündür ${ }^{89}$. Bu nedenle, Yönetmelik md. 7/2'deki kamu kurum ve kuruluşlarında çalışanların teşvik ödülünü talep edemeyeceği kuralı, SMK md. 113/4'e göre hukuka uygundur.

89 Örneğin, gerek SMK ile gerek Yönetmelik ile kamu kurum ve kuruluşlarında çalışanlar için ödenecek bedelde asgari ve azami sınırlar belirlenmiştir. Ayrıca, kamu kurum ve kuruluşlarında çalışanlar için ödenecek bedelin belirlenmesi bakımından SMK ve Yönetmelik’te çalışan buluşlarına ilişkin genel kurallardan ayrıksı düzenlemeler öngörülmüştür. 


\section{Buluşa İlişkin Bedel Hakkı}

\section{Tam Hak Talebinin Bulunması Halinde}

\section{a. Bedelin Belirlenmesi}

\section{aa. Mevzuata Göre Bedelin Belirlenmesi}

\section{aaa. Kamu Kurum ve Kuruluşlarında Çalışanlar Yönünden}

SMK md. 113/5 kamu kurumlarında çalışanların talep edebileceği bedel yönünden asgari ve azami sınırlar öngörmektedir. Buna göre, kamu kurum ve kuruluşlarında çalışanlar için ödenecek bedel, buluştan elde edilen gelirin üçte birinden az olamaz. SMK'de bu hususta "buluştan elde edilen gelir" ifadesine yer verilmekteyken, Yönetmelik md. 11/3'te esas alınacak miktarın "buluştan elde edilecek net gelir" olacağı düzenlenmektedir. Buna göre, çalışana ödenecek bedel açısından esas alınacak miktar, buluştan elde edilen kazançtan buluşun kullanılması için yapılan maliyetler ile vergi gibi yükümlülüklerin mahsup edilmesinden sonra ortaya çıkacak miktardır.

Buluş, yalnızca ilgili kamu kurum ve kuruluşu tarafından kullanılmaktaysa, çal1şana ödenecek bedel, çalışanın aldığı net ücret üzerinden belirlenmektedir. Bir başka ifadeyle, ilgili kamu kurum veya kuruluşu buluşu kullanmak suretiyle üçüncü kişilerden gelir elde etmiyorsa çalışana verilecek bedel, çalışanın aldığı net ücret üzerinden hesaplanmaktadır. Buna göre, çalışana ödenecek bedel, bedelin ödeneceği ay çalışanın aldığ 1 net ücretin on katına kadar belirlenebilmektedir. Gerek SMK'de gerek Yönetmelik'te çalışana ödenecek net miktarın hangi usule göre veya kim tarafından belirleneceği açıklanmamaktadır. Bu nedenle, taraflar arasında bir anlaşmanın olmaması halinde çalışana ödenecek miktarın tahkim yoluyla belirlenmesi gerekmektedir. Kanaatimizce, bu miktar hesaplanırken SMK md. 115/7 ve Yönetmelik md. 14 hükümleri dikkate alınmalıdır.

Kamu görevlilerinin gerçekleştirdikleri buluşların, hem ilgili kamu kurumu tarafından hem de üçüncü kişiler tarafından kullanılması durumunda, doktrinde bedelin karma bir usulle belirleneceği ileri sürülmektedir ${ }^{90}$. Bu görüşe göre, kamu kurumlarının üçüncü kişilerden buluş nedeniyle elde edeceği gelir bakımından SMK md. 113/5'te yer

90 SULUK / KARASU / NAL, 2019, s. 258, dn. 35. 
alan asgari 1/3 oranı; kurumun kendisinin kullanması nedeniyle çalışana ödenen net ücret esas alınmalıdır.

\section{bbb. Diğer Çalışan Buluşları Yönünden}

551 sayılı KHK md. 24'te bedelin belirlenmesi ve uyuşmazlık halinde izlenecek tahkim usulünün yönetmelikle düzenleneceği öngörülmüştü. Ancak bu konuda, KHK döneminde ilgili bakanlık bir çalışma yapmamıştır ${ }^{91}$. Bu nedenle, doktrinde, 551 sayılı KHK'nin uygulandığı dönemde gerçekleşen buluşlara ilişkin bedel uyuşmazlıklarının mahkemelerde çözümleneceği ileri sürülmüştür ${ }^{92}$. SMK'nin ve Yönetmeliğin yürürlüğe girmesiyle bu konudaki yasal boşluk giderilmiştir.

Çalışanın bedel isteme hakkına ilişkin hükümler, SMK md. 115'te yer almaktadır. SMK md. 115/6'ya göre, işveren tam hak sahipliği talebinde bulunursa, çalışan makul bir bedelin kendisine ödenmesini isteyebilir. SMK md. 115/7'de bedel tespit edilirken dikkate alınacak bazı özelliklere yer verilmektedir. Buna göre, buluşun ekonomik olarak değerlendirilebilirliği, çalışanın işletmedeki görevi ve buluşun gerçekleştirilmesindeki payı bedelin tespitinde dikkate alınır. Bu özellikler, SMK'de sınırlı sayıda öngörülmemiştir. Bu nedenle, örneğin, işletmenin menfaatleri gereği buluş için patent başvurusunda bulunulmadığ 1 durumlarda, patent başvurusunda bulunmamanın doğurduğu risk ve çalışanın buluş için adının belirtilmesine yönelik manevi hakkı, çalışana ödenecek bedelin belirlenmesinde dikkate alınabilir ${ }^{93}$.

SMK md. 115/7'de bedelin belirlenmesi sırasında buluşa ilişkin birçok faktörün dikkate alınabileceği düzenlenmektedir. Oysa Yönetmelik md. 7/1 ve md. 8/2'deki düzenlemelerden ${ }^{94}$, bedel hakkı belirlenirken yalnızca işverenin buluştan elde edeceği "faydalanmanın"95 esas alınacağı sonucu çıkarılmaktadır. Bahsi geçen Yönetmelik hü-

91 CANBOLAT, 2007, s. 234.

92 CANBOLAT, 2007, s. 234.

93 SMK md. 116/1.

94 Yönetmelik md. 7/1: “...Bu durumda çalışan, işverenden buluştan faydalanma karşılığı olarak bedel isteyebilir." Yönetmelik md. 8/2: “...çalışan, buluştan faydalanma karşılığı olarak işverenden kendisine bedel ödemesini isteme hakkı doğar."

95 Yönetmelik’te "faydalanma" kavramılla ifade edilmek istenen buluşun işveren tarafindan "kullanılma hakkı" ise daha teknik bir ifade olan "kullanma" kavramının kabulü daha isabetli olacaktır. Zira "faydalanma" ifadesi buluşun kullanılması olarak anlaşılabildiği gibi buluştan ekonomik menfaat 
kümlerinin, SMK ve Yönetmelik'te yer alan bedel hakkına ilişkin genel ilkelere uygun olarak yorumlanması daha isabetli olacaktır. Örneğin, çalışana ödenecek bedelin tespitinde yalnızca işverenin buluştan elde ettiği maddi menfaat değil, buluş sayesinde elde ettiği rekabet üstünlüğü ve SMK md. $115 / 7$ 'de belirtilen özellikler de dikkate alınmal1dir.

SMK md. 115/10'a ve Yönetmelik md. 11/2'ye göre, buluşun birden çok çalışan tarafından gerçekleştirilmesi halinde ödenecek bedel, her bir çalışan için ayrı ayrı belirlenmelidir. Bu sayede, buluşun gerçekleşmesindeki katkı oranına göre, her bir çalışana ödenecek bedel tespit edilmektedir. Buluşun birden fazla çalışan tarafından gerçekleştirilmesi ve çalışanların buluşun gerçekleşmesinde birbiriyle çelişen katkı oranlarını bildirmesi halinde, hangi çalışanın ne oranda katkısının olduğunu işveren belirleyebilir ${ }^{96}$. Ancak işverenin kararı taraflar arasında uyuşmazlığ 1 gidermezse, bu oran, Yönetmelik md. 24/4 gereği tahkim yoluyla belirlenmelidir.

SMK md. 115/11'de, yönetmelik ile çalışan buluşlarına ilişkin bir bedel tarifesinin hazırlanacağı öngörülmektedir. Bu doğrultuda, çalışanlar için ödenecek bedel tarifesi, Yönetmelik md. 10-21 arasında ele alınmaktadır. Yönetmelik’te yer alan düzenlemeye göre, öncelikle işverenin buluş sayesinde elde ettiği gelir tespit edilmektedir. Diğer yandan, söz konusu buluş, belirli kıstaslara göre gruplara ayrılmaktadır. Daha sonra, buluşların ait olduğu gruplar ve elde edilen kazancın net asgari ücret miktarı bakımından oranı dikkate alınarak katsayılar belirlenmektedir. Bedel tarifesi, bu katsayılara göre hesaplanmaktadır.

Yönetmelik md. 10/3'te buluştan elde edilen kazanç, buluşun ticari işlemlere konu edilmesi suretiyle elde edilen kazançların toplamı olarak öngörülmektedir. Yönetmelik md. 12/1'e göre, buluştan elde edilen kazanç, 03.04.2007 tarih ve 26482 sayılı 1 Seri

temin etme anlamına da gelebilmektedir. $\mathrm{Bu}$ durum ise bedelin belirlenmesi aşamasında uyuşmazlıklara neden olabilecektir. Örneğin patentin gelir getirme potansiyeli çok yüksek iken işveren çalışana bedel ödeyeceği zamana kadar bu potansiyeli yeterince kullan(a)mayabilir. Oysa bu durum patentin koruma süresi dikkate alındığında bedelin belirlenmesi açısından çok dikkate alınmamalıdır. Yönetmelik'te faydalanma yerine kullanma ifadesinin tercih edilmesi, Yönetmelik md. 10/1'e uygun olacağı gibi, kullanma kavramının tercih edildiği SMK ve Yönetmelik'le de uyumlu olacaktır.

96 CANBOLAT, 2007, s. 204. 
nolu Kurumlar Vergisi Genel Tebliği'nde ${ }^{97}$ yer alan esaslara göre belirlenmektedir. Buluştan elde edilen kazanç, Tebliğ'e göre belirlenmemişse, Yönetmelik md. 13-15 arasındaki hükümlerde öngörülen yöntemlerden birine göre tespit edilir. Bu yöntemler sirasıyla kıyas, işletmenin buluştan sağladığı belirlenebilen yarar ve tahmin yöntemleridir.

Kıyas yöntemi, Yönetmelik md. 13’te düzenlenmektedir. Bu yönteme göre, çal1şanın buluşu, benzer nitelikteki ürün veya usullerin bulunduğu endüstri dallarında bulunan bir serbest buluş ile kıyaslanmaktadır. Buluştan elde edilen kazanç, kıyas alınan buluş(lar)a ilişkin lisans sözleşmeleri veya satış bedelleri dikkate alınarak hesaplanmaktadır. Ancak, buluşla kıyaslanabilir nitelikte bir buluşun var olmaması halinde; buluştan elde edilen kazanç, ürünün satış fiyatına buluşun katkısı dikkate alınarak bulunmaktadır. Bu konuda Yönetmelik Ek-1'de bir örneğe yer verilmektedir. Buna göre, satış fiyatı 1000 TL olan bir üründe, buluşun ürünün satış fiyatına katkısı 10 TL'dir. Buluşu içeren ürünlerden 1 milyon adet satış gerçekleşmiştir. Buluştan elde edilen kazanç, buluşun satış fiyatına katkısı ile ürünün satış miktarı çarpılarak hesaplanmaktadır. Böylece, somut olayda, buluştan elde edilen kazanç, 10 milyon TL'dir.

İşletmenin buluştan sağladığı yarar yöntemi, Yönetmelik md. 14'te düzenlenmektedir. $\mathrm{Bu}$ yönteme göre, buluşun kullanılması sonucu işletmenin masrafları ile gelirleri arasında doğan pozitif fark, işletmenin buluştan elde ettiği kazançtır. Bu yönteme göre, buluştan elde edilen kazancın tespitinde işveren buluşun gerçekleşmesi için yaptığı masrafları, sağladığı yararlardan mahsup edemez(Yönetmelik md. 14/3). İşverenin buluşun gerçekleşmesi için yaptığı masrafları elde edilen kazançtan mahsup edemediği tek durum bu yöntemin uygulanmasında söz konusu olmalıdır. Aksi halde, işverenin menfaati büyük ölçüde zedelenmektedir. Bir başka ifadeyle, bütün çalışan buluşları bakımından işverenin buluşun gerçekleşmesi için yaptığı yatırımların buluştan elde edilen kazancın tespitinde dikkate alınmaması, işverenin hukuki menfaatlerini hakkaniyete aykırı biçimde sinırlandırmaktadır ${ }^{98}$.

97 Tebliğ için bkz. http://www.gelirler.gov.tr/node/87461 (erişim tarihi: 15.09.2019).

98 Zira Yönetmelik md. 16 ve md. 17'ye göre buluşun gerçekleştirilmesinden sonra yapılan masraflar kazancın belirlenmesinde dikkate alınırken öncesinde yapılan masrafların göz ardı edilmesinde bir gerekçe bulunmamaktadır. 
Son olarak tahmin yöntemi, Yönetmelik md. 15’te düzenlenmektedir. Bu yöntem, diğer yöntemlerin uygulanamadığı durumlarda uygulanır. $\mathrm{Bu}$ yönteme göre, buluşun üçüncü bir kişi tarafından gerçekleştirilmesi ve işveren tarafından satın alınması varsayımında; işverenin ödemek zorunda kalacağı makul bedel, buluştan elde edilen kazanç olarak esas alınır.

İşveren, buluşu bizzat kullanabileceği gibi üçüncü kişilere lisans hakkı da tanıyabilir. Ayrıca işverenin buluşa ilişkin patent hakkını devretmesi de mümkündür. İşverenin üçüncü kişilerle yapacağı lisans ve satış sözleşmelerinden elde edeceği net gelir, buluştan elde edilen kazancın belirlenmesinde dikkate alınmaktadır. Yönetmelik md. 16 ve md. 17'ye göre, işverenin lisans ve satış sözleşmesinden elde ettiği net gelir hesaplanırken işverenin patente ilişkin yaptığı bütün masraflar mahsup edilebilmektedir ${ }^{99}$.

Yönetmelik md. 20'de, SMK md. 115/7'de belirtilen ilkelere göre hizmet buluşlar1 gruplara ayrılmaktadır. Yönetmelik md. 20/1'e göre,

a) İşletmedeki görev alanına doğrudan girmeyen konularda çalışanın kendi kendine üstlendiği bir görev vesilesiyle ve buluşun gerçekleştirilmesine işletmenin katkısının olmadığı durumda gerçekleştirilen buluşlar birinci grup,

b) İşletmedeki görevlendirmenin doğrudan neden olmadığı ancak işletme tarafından tespit edilen ihtiyacın giderilmesi veya sorunların çözümü için gerçekleştirilen veya buluşun gerçekleştirilmesine işletmenin katkısının olduğu buluşlar ikinci grup,

c) İşletmede verilen görevlendirmenin doğrudan neden olduğu ve buluşun gerçekleştirilmesine işletmenin tam katkısının olduğu durumda gerçekleştirilen buluşlar üçüncü grup buluş olarak sınıflandırılmaktadır.

Yönetmelik md. 21/1'de hizmet buluşu için çalışana ödenecek bedelin Yönetmelik md. 20/1'e göre buluşun ait olduğu grup esas alınarak Yönetmelik md. 21/3'te yer alan tabloya göre belirleneceği öngörülmektedir.

99 Teknik olarak patent hakkının kullanılması, buluşun bizzat patent sahibi tarafından kullanılmasının yanı sıra patent sahibinin yaptığı lisans sözleşmelerini de kapsamaktadır. $\mathrm{Bu}$ nedenle, lisans sözleşmeleri açısından buluştan elde edilen kazanç tespit edilirken, patent sahibinin patent hakkını koruması için üstlendiği her türlü masrafı mahsup edebileceğine ilişkin hükmün, yalnızca Yönetmelik md. 16 kapsamında öngörülmemesi daha isabetli olurdu. Bu sayede, buluşun işletme tarafından üretimde kullanılması ile lisans yoluyla kullanılması arasında bir farklılık oluşması da önlenebilirdi. 
Yönetmelik 21/3'e göre, hizmet buluşları için ödenecek bedelin tespitinde aşağ1daki tabloda yer alan oranlar dikkate alınacaktır:

\begin{tabular}{|c|c|c|c|c|c|c|c|}
\hline & \multicolumn{7}{|c|}{ Buluştan Elde Edilen Net Asgari Ücret Miktarının } \\
\hline $\begin{array}{l}\text { Buluşun } \\
\text { Ait Oldu- } \\
\text { ğu Grup }\end{array}$ & $\begin{array}{l}1.000 \\
\text { katına } \\
\text { kadarki } \\
\text { bölümü } \\
\text { için } \\
\text { katsayı }\end{array}$ & $\begin{array}{l}1.000 \text { ile } \\
5.000 \text { katı } \\
\text { arasındaki } \\
\text { miktar için } \\
\text { katsayı }\end{array}$ & $\begin{array}{l}5.000 \text { ile } \\
10.000 \text { katı } \\
\text { arasındaki } \\
\text { miktar için } \\
\text { katsayı }\end{array}$ & $\begin{array}{l}10.000 \text { ile } \\
25.000 \text { katı } \\
\text { arasındaki } \\
\text { miktar için } \\
\text { katsayı }\end{array}$ & $\begin{array}{l}25.000 \text { ile } \\
50.000 \text { katı } \\
\text { arasındaki } \\
\text { miktar için } \\
\text { katsayı }\end{array}$ & $\begin{array}{l}50.000 \text { ile } \\
100.000 \\
\text { katı ara- } \\
\text { sındaki } \\
\text { miktar için } \\
\text { katsayı }\end{array}$ & $\begin{array}{l}100.000 \text { ile } \\
150.000 \text { katı } \\
\text { arasındaki } \\
\text { miktar için } \\
\text { katsayı }\end{array}$ \\
\hline 1. Grup & 0,0060 & 0,0050 & 0,0040 & 0,0030 & 0,0020 & 0,0010 & 0,0006 \\
\hline 2. Grup & 0,0040 & 0,0030 & 0,0020 & 0,0016 & 0,0012 & 0,0008 & 0,0005 \\
\hline 3. Grup & 0,0020 & 0,0015 & 0,0012 & 0,0010 & 0,0008 & 0,0006 & 0,0004 \\
\hline
\end{tabular}

Yönetmelik md. 21/3'e göre bedelin hesaplanmasına ilişkin örnek bir olaya Yönetmelik Ek-1'de yer verilmektedir. Ekte yer alan örneğe göre, iş makineleri üreten bir işletmede çalışan mühendis, işverenin talimatları doğrultusunda bir buluş gerçekleştirmiştir. İşverenin bedeli ödeyeceği yıl için net asgari ücret miktarı 1.400 TL'dir. Buluştan elde edilen kazanç ise 10 milyon TL'dir. Somut olayda, öncelikle çalışanın buluşunun ait olduğu grup tespit edilmelidir. Yönetmelik md. 20/1' göre somut olaydaki buluş üçüncü gruba aittir. Bu nedenle, buluştan elde edilen kazancın net asgari ücret miktar1nin,

a) 1.000 katına kadar olan 1.400.000 TL'ye kadar olan bölümü için; 0,0020,

b) 1.000 katı ile 5.000 katı arasındaki 5.600.000 TL'lik bölüm için; 0,0015,

c) 5.000 katı ile 10.000 katı arasındaki 3.000.000 TL'lik bölüm için; 0,0012 katsayıları esas alınmaktadır.

Bu katsayılar dikkate alınarak ödenecek bedel aşağıdaki şekilde hesaplanmaktadır:

a) $1.400 .000 \mathrm{TL}$ 'lik kazancin 0,0020 katı: $2.800 \mathrm{TL}$

b) $5.600 .000 \mathrm{TL}$ 'lik kazancın 0,0015 kat1: $8.400 \mathrm{TL}$ 
c) 3.000.000TL'lik kazancın 0,0012 katı: 3.600 TL. Sonuç olarak, çalışan somut olayda toplam 14.800 TL bedel isteme hakkına sahip olmaktadır ${ }^{100}$.

Çalışana ödenecek bedelin tespitinde, buluş hangi grup altında nitelenirse nitelensin, buluştan elde edilecek kazancın net asgari ücret bakımından orantısı dikkate alınmaktadır. Ayrıca, Yönetmelik md. 21/2'de işverenin, buluştan elde ettiği ve net asgari ücret miktarının 150.000 katını aşan miktar bakımından bedel ödeme yükümlülüğü olmadığı düzenlenmektedir.

\section{bb. Bedelin Sözleşme ile Belirlenmesi}

SMK md. 117 ve Yönetmelik md. 25'te emredici nitelikte hükümler öngörülmesi ve emredici nitelikte hükümlerin bedel hakkı için de geçerli olduğunun açıkça belirtilmesi nedeniyle, uygulamada taraflar arasında kurulacak sözleşmenin geçerliliği açısından tereddütler oluşmuştur ${ }^{101}$. Bu nedenle öncelikle, hizmet buluşları için taraflar arasında sözleşme kurulup kurulamayacağı üzerinde durulmalıdır.

Taraflar arasında hizmet buluşları için sözleşme yapılabilmesi bizzat SMK hükümlerinin yorumundan çıkarılabilmektedir. SMK md. 115/9'da bedel ve ödeme şeklinin, işveren ile çalışan arasında kurulacak sözleşmeye göre belirleneceği açıkça belirtilmektedir. SMK md. 117/1'de taraflar arasında sözleşme kurma serbestisinin zamanına ilişkin hükümler öngörülmektedir. Son olarak, SMK md. 115/6 ve Yönetmelik md. 7/1'e göre, bedel isteme hakkı çalışanın takdirine bırakılmaktadır. Başka bir ifadeyle, çalışanın işverenden bedel talebinde bulunmaması, ihtimaller arasında yer almaktadır. Bu nedenle, çalışanın bedel talep edip etmemesi kendi iradesindeyken, bu bedelin belirlenmesi ve ödenmesi açısından Yönetmelik'le belirlenen tarifeye göre hareket etmek zorunda olduğunu ileri sürmek, mümkün görünmemektedir. Ayrıca çalışan, serbest bir buluşuna ilişkin patent başvuru hakkını veya patent hakkını işverene devredebilir. $\mathrm{Bu}$

100 Yönetmelik md. 7/2 gereği, bu bedele çalışana ödenecek teşvik ödülü dâhil değildir.

101 11.01.2018 tarihinde TÜRKPATENT’te yapılan “Çalışan Buluşlarına, Yükseköğretim Kurumlarında Gerçekleştirilen Buluşlara ve Kamu Destekli Projelerde Ortaya Çıkan Buluşlara Dair Yönetmelik Uygulama Çalıştayı"nda bu tereddütlerin giderilmesi adına genelge/tebliğ niteliğinde bir mevzuat hazırlanması amacıyla çalışma grupları oluşturulmasına karar verilmiştir. Ancak makalenin yayınlandığı tarih itibariyle bu konuda somut bir çalışma/mevzuat yayınlanmamıştır. 
nedenle, hak sahipliğine ilişkin kanuni bir düzenleme, çalışan ile işveren arasında hukuki işlem kurulması zeminini ortadan kaldıracak şekilde dar yorumlanmamalıdır.

Tarafların bedel konusunda sözleşme kurabileceği, Yönetmelik hazırlanırken dikkate alınan Alman hukukuna bakılarak da söylenebilir. Alman İşçi Buluşları Kanunu md. 23/1'e göre ${ }^{102}$, çalışan ile işveren arasında hakkaniyete aykırılık oluşturmadığı sürece bedele ilişkin yapılan anlaşmalar geçerlidir ${ }^{103}$.

SMK ve Yönetmelikte yer alan düzenlemeler, taraflar arasında sözleşme kurma özgürlüğünü ortadan kaldırmamaktadır; yalnızca çalışanın korunması amacıyla bazı ilkeler benimsemektedir. Bu ilkeler, sözleşme kurma serbestîsine getirilen sınırlama ile bedelin hakkaniyete aykırı olmamasıdır.

Çalışan ile işveren arasında sözleşme kurma serbestisine getirilen sınırlama, SMK md. 117/1 ile Yönetmelik md. 11/1'de düzenlenmektedir. Yönetmelik md. 11'e göre, işveren ile çalışanın bedel ve ödeme şekli konusunda anlaşabilmeleri, işverenin tam veya kısmi hak sahipliğine ilişkin kararını çalışana bildirmesinden sonra mümkündür. Buna göre, taraflar arasında sözleşme kurulabilmesi için işverenin hak sahipliğine ilişkin kararını bildirmesi yeterlidir. Oysa SMK md. 117/1'e göre taraflar arasında sözleşme kurma serbestîsi, hizmet buluşları için işverenin patent başvurusunda bulunmasından, serbest buluşlar için çalışanın bildirim yükümlülüğünü yerine getirmesinden sonra mümkündür. $\mathrm{Bu}$ nedenle, Yönetmelik md. 11, taraflar arasında sözleşme yapma serbestîsini serbest buluşlar için ertelerken, hizmet buluşları için öne almaktadır. Çalışan buluşlarına ilişsin düzenlemelerin emredici nitelikte olduğu dikkate alındığında, hizmet

102 Kanun metni için bkz. http://www.wipo.int/wipolex/en/text.jsp?file_id=126210 (erişim tarihi: 15.09.2019).

103 Almanya'daki düzenlemenin yanı sıra, diğer ülkelerin mevzuatında yer alan sözleşme kurma serbestliğine ilişkin düzenlemeler, tarafların bedel konusunda anlaşabileceklerini desteklemektedir. Örneğin 13.04.1959 tarih ve 121 sayılı Japonya Patent Kanunu md. 35/5'te hakkaniyete aykırı olmaması şartıyla taraflar arasında sözleşmenin kurulabileceği; Fransa Fikri Mülkiyet Kanunu md. L611-7/2'de tarafların çalışanın talep edebileceği adil bir bedel konusunda anlaşamamaları durumunda md. L615-21'de öngörülen alternatif uyuşmazlık çözüm yoluna başvurabilecekleri görülmektedir. Yine Macaristan Patent Kanunu md. 15/2'de taraflara buluş konusunda ödenecek bedele ilişkin sözleşme imkânı getirildiği gibi ödenecek bedelin götürü bedel niteliğinde olabileceği öngörülmektedir. Örneklerde belirtilen madde metinleri için sırasıyla bkz. http://www.wipo.int/wipolex/en/text.jsp?file_id=403366 https://www.legifrance.gouv.fr/content/download/1959/13723/.../3/file/Code_35.pdf http://www.wipo.int/wipolex/en/text.jsp?file_id=190654 (erişim tarihi: 15.09.2019). 
buluşları için SMK md. 117/1'in, serbest buluşlar için Yönetmelik md 11/1'in dikkate alınması gerekir. SMK md. 116/2'ye göre işverenin patent başvurusunda bulunma yükümlülüğüne muafiyet getirilen hallerde ise, Yönetmelik md. 11/1 esas alınmalıdır. Taraflar arasında, bu tarihlerden önce yapılacak sözleşmeler, özellikle tüm buluş haklarının devrini ve ödenecek bedelden çalışanın feragat etmesini içeren anlaşmalar geçersiz$\operatorname{dir}^{104}$.

SMK ile Yönetmelik’te benimsenen bir diğer ilke, kararlaştırılan bedelin hakkaniyete aykırı olmamasıdır. SMK md. 117/3 ve Yönetmelik md. 26/2'ye göre, belirlenen bedelin hakkaniyete aykırı olması halinde, çalışan, iş sözleşmesinin sona ermesini müteakip altı ay içinde yazılı olarak hakkaniyete aykırılık durumunu ileri sürmelidir. Hakkaniyete aykırılık itirazına ilişkin mevzuatta öngörülen süre hak düşürücü niteliktedir. SMK ve Yönetmelik'te itirazın ileri sürüleceği merciiye ilişkin bir açıklama bulunmamaktadır. Ancak, düzenlemenin getirilme sebebi dikkate alındığında, hakkaniyete aykırılık itirazının tahkim açısından hakem veya hakem heyetine, arabuluculuk açısından arabulucuya ileri sürülmesi gerektiği kabul edilmelidir.

Uygulamada, Yönetmelik’te yer alan bedel tarifesine ilişkin hükümlerin hakkaniyete aykırılık açısından bir eşik niteliğine sahip olup olmadığı konusunda tereddüt bulunmaktadır. Çünkü taraflar arasında kararlaştırılan bedelin, Yönetmelik’teki tarifeye göre tespit edilecek bedelden daha az olması halinde, taraflar arasında uyuşmazlık çıkabilir. Kararlaştırılan bedel ile Yönetmeliğe göre tespit edilecek bedel arasında bir farkın olup olmayacağının önceden tespiti ise fiili ve hukuki olarak imkânsızdır. Zira Yönetmelik’teki tarife esas alınarak bedelin tespitinde ödemenin yapılacağı yıla ilişkin net asgari ücret miktarının esas alınması, bedelin önceden belirlenmesini hukuken imkânsız kılmaktadır. Elde edilecek kazancın önceden belirlenmesi ise ticari hayatın tabii niteliği gereği fiili olarak imkânsızdır. Yönetmelikteki bedele ilişkin düzenlemenin, tarafların anlaşamamaları halinde, uyuşmazlığı çözmeye yetkili kişinin dikkate alacağı bir düzenleme olarak kabulü daha uygun olur. Bu kabulün geçerli olması halinde, taraflar arasında kararlaştırılan bedel ile Yönetmeliğe göre belirlenecek bedel arasındaki farka ilişkin

104 GÜNEŞ, 2017, s. 154. 
hakkaniyete aykırılık itirazı, 6098 sayılı Türk Borçlar Kanununda ${ }^{105}$ düzenlenen gabin durumuna yakın olması halinde kabul edilmelidir. Ayrıca tarafların bedele ilişkin miktar1 tespit ederken Yönetmelik md. 13-15 arasındaki hükümlere göre buluştan elde edilebilecek kazancı tespit etmeleri, ileride hakkaniyete aykırılık itirazının önüne geçmekte faydalı olur.

\section{b. Bedelin Ödenmesi}

Buluşa ilişkin bedel ödeme yükümlülüğü işverene aittir. İşverenin patenti veya patent isteme hakkını daha sonra üçüncü bir kişiye devretmiş olması, işverenin çalışana olan borcunun nakli sonucunu doğurmaz ${ }^{106}$. Başka bir ifadeyle, işverenin buluş üzerinde yapacağı tasarruflar, çalışanın işverene karşı olan bedel hakkını etkilemez ${ }^{107}$.

SMK md. 115/8'e göre, işveren, tam hak sahipliği talebinde bulunduktan sonra, buluşun ekonomik açıdan önemsiz olduğunu ileri sürerek bedel ödeme yükümlülüğünden kaçınamaz. Ancak, Yönetmelik md. 23/2'de, patent hakkının ekonomik işlevi bedel ödeme yükümlülüğünü ortadan kaldıracak ölçüde ortadan kalkmışsa, işverenin bedel ödeme yükümlülügünün olmayacağı öngörülmektedir. Yönetmelik’te yer alan ekonomik işlevin ortadan kalkması ölçütü objektif niteliğe sahip olmalıdır. Örneğin, buluşun ait olduğu faaliyet alanında çok hızlı teknolojik gelişmeler yaşanmış olabilir. Bu nedenle buluşun ticari olarak kullanımı işverenin kendisinden beklenmeyecek ölçüde ekonomik çıkarlarına uygun olmayabilir. Ancak buluşun ticari olarak kullanımının mümkün olduğu hallerde işverenin patenti kullanmayı tercih etmemesi, bedel ödeme yükümlülüğünü ortadan kaldırmaz. Nitekim Alman Patent Ofisi Hakem Kurulunun 07.05.2014 tarih ve 030/03 sayılı Datenbank kararına göre, işveren tarafından patenti alınan ancak kullanılmayan bir hizmet buluşu için çalışan, buluşun değerinin belirlenmesinden sonra belli bir nisapta bedel isteme hakkına sahiptir ${ }^{108}$.

\footnotetext{
105 RG. 04.02.2011, Say1: 27836.

106 CANBOLAT, 2007, s. 219-220.

107 CANBOLAT, 2007, s. 237; Bu görüş doğrultusunda verilen "Zhang v. 3M" kararı için bkz. BAİ, Benjamin, Inventor Remuneration: Have a Company Policy, Kluwer Patent Blog, 24.09.2015, http://patentblog.kluweriplaw.com/2015/09/24/inventor-remuneration-have-a-company-policy/ (erişim tarihi: 15.09.2019).

108 GÜNEŞ, 2017, s. 168.
} 
Yönetmelik md. 22'de, kararlaştırılan bedelin ödenme şekli düzenlenmektedir. Buna göre, bedelin ödenme şekli, bedelin belirlenme usulü ile yakından ilgilidir. Şayet taraflar bedele ilişkin aralarında anlaşırlarsa, bedelin ifa zamanına ilişkin konuları da belirleyebilirler. Buna göre, bedelin, taraflar arasındaki anlaşmaya göre götürü olarak ${ }^{109}$ veya yıllık buluş üzerinden elde edilecek kazanca göre; peşin veya taksitle ödenmesi mümkündür. Tarafların bedelin belirlenmesinde Yönetmelik hükümlerinin dikkate al1nacağını kararlaştırması halinde, işveren yıllık dönemler halinde bedel miktarının belirlenmesi üzerine, bedeli öder. Ayrıca taraflar, anlaşmada işverenin bir yılı aşan dönemler halinde de bedeli ödeyebileceğini kararlaştırabilmektedirler ${ }^{110}$.

SMK md. 118/4'e göre çalışan buluşlarından doğan hak ve yükümlülükler, taraflar arasında bulunan iş sözleşmesinin sona ermesinden etkilenmez. Bu nedenle, bedelin ödenmesi konusunda Yönetmelik’teki hükümlerin esas alınması ve çalışan ile işveren arasındaki iş sözleşmesinin patentin koruma süresinden önce sona ermesi halinde, çal1şana yapılacak ödemelerin vergi düzenlemeleri ve muhasebe açısından niteliğinde tereddütler yaşanmaktadır. İşverenlerin, bu yöndeki tereddütlerini gidermesi için iş sözleşmesinin sona ermesinden sonra, çalışan ile götürü usule göre bir bedel kararlaştırmaları mümkündür. Ayrıca işveren ile çalışan, Yönetmelik md. 24/3'e göre tahkime başvurabilirler.

Çalışanın buluş nedeniyle işverenden alacağı bedel hakkı, SMK md. 120/2'de imtiyazlı alacak olarak belirlenmiştir. SMK'de bu yönde bir düzenleme öngörülmesi iki açıdan faydalı olmuştur. İlk olarak, bedel hakkının 2004 sayılı İcra ve İflas Kanunu ${ }^{111}$ md. 206/4-(A) kapsamında imtiyazlı alacak olarak kabul edilmesi açısından SMK md. $118 / 4$ 'te iş sözleşmesinden bağımsız nitelikte olduğunun öngörülmesinin neden olabileceği tereddütler ortadan kaldırılmıştır. İkinci olarak, SMK'de tanımlanan çalışan kavramının 2004 sayılı İIK' de ve 4857 sayılı İş Kanunu'nda yer alan işçi kavramından daha

109 Tarafların, ödenecek bedeli, götürü usule göre hesaplayabilecekleri yönünde Alman Federal Mahkeme'sinin 20.11.1962 tarih ve "I ZR 40/61" say1l "Pauschalabfindung" kararı için bkz. HARGUTH, Alexander / CARLSON, Steven, Patents in Germany and Europe. Procurement, Enforcement and Defense - An International Handbook, Bedfordshire 2011, s. 241.

${ }^{110}$ Bir yılı aşan sürelerde ödemenin yapılacağı kararlaştırmışsa, bedelin belirlenmesinde ödemenin yapılacağı yıl kabul edilen asgari ücret miktarı esas alınır.

111 RG. 09.06.1932, Say1: 2128. 
geniş bir kapsama sahip olduğu düşünüldüğünde, bu yönde bir düzenlemenin yapılması faydalı olmuştur.

\section{2. İşverenin Kısmi Hak Talebinin Bulunması Halinde}

İşverenin kısmi hak talebinde bulunması halinde, hizmet buluşu serbest buluş haline gelir. Bu halde, işveren inhisari olmayan bir lisans talebinde bulunabilir. Ancak diğer lisans sözleşmelerinden farklı olarak, işverenin kısmi hak talebi karşısında bedel ödeme yükümlülüğü buluşu kullanmasına bağlıdır. Bu durum, SMK md. 115/6’da 'buluşu kullanması halinde" ifadesi ile düzenlenmektedir.

551 sayılı KHK'de kısmi hak talebinde bulunulması halinde çalışana verilecek bedel için hizmet buluşunda var olan KHK md. 22/2'deki kriterlerin uygulanacağı öngörülmüşken; SMK'de bu yönde bir düzenlemeye yer verilmemektedir. Kısmi hak talebinde işverenin buluşa ilişkin bir lisans hakkı oluşacağ için lisans sözleşmelerindeki ücret uygulamasının dikkate alınması isabetli olacaktır ${ }^{112}$.

\section{Bedel İsteme Hakkının Sona Ermesi}

Çalışanın bedel isteme hakkı, buluşun patent korumasının kalkması veya alacağın zamanaşımına uğraması ile sona erer.

SMK md. 115/8'de, buluşun patent korumasından faydalanamayacağına ilişkin bir mahkeme kararı olduğunda, çalışanın bedel isteme hakkının olmadığı; bu yönde bir talepte bulunamayacağı düzenlenmektedir. Başka bir ifadeyle, işverenin bedel ödeme yükümlülüğü, mahkeme tarafından buluşun korunabilir olmadığına karar verilmesi halinde sona ermektedir. SMK md. 115/8'de yer alan dava ve buluşun korunabilir nitelikte olmadığı ifadeleriyle patentin hükümsüzlügüne karar verilmesi kast edilmektedir. Bunun dışında, patente karşı hükümsüzlük davası açılması, başlı başına işverenin yükümlülüğünü ortadan kaldırmaz veya azaltmaz. Ancak patent hakkında açılan bir hükümsüzlük davası veya patent başvurusunun reddedilmesi riski, buluştan elde edilen kazancı etkilediği oranda çalışana ödenecek bedelin belirlenmesinde dikkate alınabilir ${ }^{113}$.

112 Lisans sözleşmelerinde ücretin belirlenmesine ilişkin detaylı bilgi için bkz. ORTAN, Ali Necip, Patent Lisansı Sözleşmesi, Doğan Basımevi, Ankara, 1979, s. 146 vd.; TOPÇU, Deniz, Patent Lisans Sözleşmeleri, Seçkin Yayıncılık, Ankara, 2016, s. 149 vd.; SARI, 2019, s. 272 vd.

113 Buna karşılık, işverenin patent başvurusunun reddedilme riskinin bulunduğu hallerde ödenecek 
SMK md. 115/8'deki düzenlemenin amacı, patent korumasına sahip olamayacak nitelikte bir başvuru için işvereni bedel ödemekle yükümlü kılmamaktır. Bu nedenle, TÜRKPATENT'in patent başvurusunun reddine karar vermesi halinde bedel isteme hakkının sona erip ermeyeceği incelenmelidir. TÜRKPATENT'in patent başvurusunu reddetmesi halinde kural olarak işverenin bedel ödeme yükümlülüğü bulunmamaktadır. Zira Yönetmelik md. 9/2'de, buluşun korunabilir olmadığına TÜRKPATENT tarafından karar verilmesi halinde de işverenin bedel ödeme yükümlülüğünün kalkacağı düzenlenmektedir ${ }^{114}$. Ancak, TÜRKPATENT'in başvuruya ilişkin kararına karşı yarg1 yoluna başvurmak mümkün olduğu için, SMK md. 116 kapsamında işverenin başvuru yükümlülüğü dikkate alınmalıdır. Bu yükümlülük kapsamında işverenin karara itiraz etmesi kendisinden beklenebilecekse, bedel ödeme yükümlülüğünün sona erdiği söylenemez. Başka bir ifadeyle, TÜRKPATENT'in verdiği karara karşı nihai yargı yolunun tüketilmesinden önce çalışanın bedel isteme hakkının devam ettiğini söylemek daha uygun olur.

551 sayılı KHK md. 23/2'ye göre, çalışan bedel talebini buluşun korunabilir olmadığına ilişkin kararın kesinleşmesine kadar ileri sürebilmekteydi. Oysa SMK md. 115/8'de mahkemenin buluşun korunabilir olmadığına karar vermesi halinde çalışanın bedel isteme hakkının sona ereceği öngörülmektedir. Böylece, buluşun korunabilir olmadığına karar verildiği andan itibaren işverenden bedel ödeme yükümlülüğünü yerine getirmesi beklenemeyecek; kararın kesinleşmesi ile işverenin borcu sona erecektir. Yönetmelik md. 9/2'de bu konuda ek bir düzenlemeye yer verilmektedir. Buna göre, buluşun korunabilir nitelikte olmadığına karar verilmesinden önce işverenin elde ettiği kazanç bakımından bedel ödeme yükümlülüğü devam etmektedir.

İşverenin bedel ödeme yükümlülüğünü sona erdiren diğer bir hal, alacağın zamanaşımına uğramasıdır. SMK md. 118/4’te, çalışanın bedel hakkının iş ilişkisinden bağımsız olduğu ileri sürüldüğü için, bedel hakkının tâbi olduğu zamanaşımının belirlenmesi önem arz etmektedir. 4857 sayılı İş Kanunu md. 32/8 ve 6098 sayılı TBK md.

bedelde \%50 indirme yetkisinin bulunduğu yönünde Alman Federal Mahkemesinin 28.06.1962 tarih ve 1692-I ZR 28/61 sayılı kararı için bkz. GÜNEŞ, 2017, s. 168.

$114 \mathrm{Bu}$ düzenlemeye, 551 sayılı KHK md. 23/2'de öngörülmesine rağmen SMK'de yer verilmemiştir. 
147'ye göre, işçinin ücret hakkı beş yıllık zamanaşımına tâbidir. Ancak çalışanın buluşa ilişkin bedel hakkı bir ücret değildir ${ }^{115}$. Bu nedenle taraflar arasında kurulan sözleşme, on yıllık zamanaşımına tâbi olmalıdır ${ }^{116}$.

\section{E. Bedele İlişkin Uyuşmazlıkların Çözümü}

SMK md. 115/11'de, çalışan buluşlarına ilişkin ortaya çıkacak uyuşmazlıklarda tahkim usulünün uygulanacağı öngörülmektedir. Hukuki niteliği itibariyle buradaki tahkim usulü zorunlu tahkimdir. SMK md. 115/11, tahkim usulüne ilişkin düzenlemelerin yönetmelikle düzenleneceğini öngörmektedir. Bu doğrultuda, tahkime ilişkin düzenlemelere Yönetmelik md. 24'te yer verilmektedir.

Yönetmelikteki tahkim usulüne ilişkin düzenlemelerde üzerinde durulacak üç önemli husus bulunmaktadır. Bunlardan ilki, Yönetmelik md. 24/2'de tahkim usulü için yazılılık şartının aranmayacağının öngörülmesidir. Tahkim sözleşmesinin yazılı şekilde yapılması kuralı 6100 sayılı Hukuk Muhakemeleri Kanunu md. 412/3 ${ }^{117}$ ve 4686 sayılı Milletlerarası Tahkim Kanunu md. 4/2'de ${ }^{118}$ öngörülmektedir. Belirtilen maddelerde yazılı şekil şartı esnetilmiş olsa da ${ }^{119}$, çalışan buluşlarında tahkim usulü zorunludur. $\mathrm{Bu}$ nedenle, anlaşamayan taraflar arasında tahkim sözleşmesinin kurulmasını aramanın ortaya çıkaracağı sorunlar yazılılık şartının aranmayacağının öngörülmesi ile ortadan kaldırılmıştır. Ancak, kanunlarla öngörülen şekil şartına SMK yerine Yönetmelik ile istisna getirilmesi isabetli olmamıştır.

Diğer bir konu, Yönetmelik md. 24/1'de tahkime başvurabilme zamanına ilişkin düzenlemedir. $\mathrm{Bu}$ düzenlemeye göre, çalışan hizmet buluşları bakımından işverenin patent veya faydalı model aldığı; serbest buluşlar için buluşu kullanmaya başladığı tarihten itibaren tahkime başvurabilecektir. Hizmet buluşları açısından bu yönde bir dü-

115 CANBOLAT, 2007, s. 236.

116 ÖZ, 2016, s. 599.

117 RG. 12.01.2011, Say1: 27836.

118 RG. 21.06.2001, Say1: 24453.

1196100 sayılı HMK md. 412/3 ve 4686 sayılı MTK md. 4/2’ye göre, yazılılık şartının sağlanması için, tahkim sözleşmesinin taraflarca imzalanmış yazılı bir belgeye veya taraflar arasında teati edilen mektup, telgraf, teleks, faks gibi bir iletişim aracına veya elektronik ortama geçirilmiş olması ya da dava dilekçesinde yazılı bir tahkim sözleşmesinin varlığının iddia edilmesine davalının verdiği cevap dilekçesinde itiraz etmemesi yeterlidir. 
zenlemenin öngörülmesiyle, işveren, SMK md. 139/2-(b) nedeniyle menfaatinin zarar görmesini engelleyebilmektedir.

Son olarak, Yönetmelik md. 24/1'de, çalışanın tahkime başvurabileceği andan itibaren, bedel konusunda iki ay müzakere etme şartı bulunmaktadır. Buna göre, taraflar iki ay içerisinde anlaşamadıkları takdirde, tahkime başvurabilirler. Yönetmelik md. 24/1'de yer alan bu düzenleme, esas olarak Yönetmelik md. 24/5'te ihtiyari nitelikte öngörülen arabuluculuk kurumunu fiili olarak zorunlu hale getirmektedir ${ }^{120}$. Ayrıca anlaşamayan taraflar için tahkim sürecinin iki ay geç başlamasına neden olmaktadır.

551 sayılı KHK md. 25/2'de tarafların tahkime başvurmaları halinde, uyuşmazlığın iki ay içinde çözümleneceği öngörülmekteydi. Tahkime ilişkin 551 sayılı KHK md. 25/2'de yer alan süre sınırlamalarına SMK ve Yönetmelik'te yer verilmemektedir. Bu nedenle hakem veya hakem heyeti 6100 sayılı HMK veya 4686 say1lı Milletler arası Tahkim Kanununda yer alan düzenlemelere göre karar vermelidir.

Türk Hukukunda, tahkim usulünün hangi kurum veya kuruluş nezdinde başlatılacağına ilişkin bir düzenleme öngörülmemektedir. Hâlbuki gerek Avrupa Patent Ofisinde $^{121}$ gerek Alman Patent Ofisinde ${ }^{122}$ çalışan buluşlarına ilişkin bedel uyuşmazlıklarının çözüme kavuşturulduğu tahkim kurulları bulunmaktadır. Türk Hukuku bakımından, TÜRKPATENT bünyesinde uyuşmazlıkların çözümü için bir tahkim kurulunun oluşturulması veya var olan tahkim merkezleri ile anlaşmaya gidilmesi mümkündür. Bu yönde bir usulün benimsenmesi, uyuşmazlıkların çözümünde tahkim usulünün etkinliğini gözlemlemek açısından faydalı olacaktır.

1207036 sayılı Kanun md. 3/1, işçinin kanuna veya sözleşmeye dayanan iş alacakları için; 6102 sayılı TTK md. 5/A konusu bir miktar alacak veya tazminat olan ticari davalar yönünden arabulucuya başvurma zorunluluğu getirmiştir. Kanaatimizce, çalışan buluşları yönünden arabuluculuğa ilişkin söz konusu düzenlemelerden 6102 sayılı TTK md. 5/A uygulama alanına sahiptir. Diğer bir ifadeyle, 7036 sayılı Kanun md. 3/1, çalışan buluşları yönünden uygulama alanına sahip değildir. Çünkü her ne kadar hizmet buluşunun mutlak unsuru olarak işveren ile çalışan arasında bir iş ilişkisi aransa da; çalışanın buluş nedeniyle elde ettiği menfaat iş ilişkisinden bağımsızdır. Nitekim SMK md. 118/4'te çalışan buluşundan doğan hak ve yükümlülüklerin iş sözleşmesinin sona ermesinden etkilenmeyeceği öngörülmektedir. 6102 sayılı TTK md. 5/A ise taraflar arasındaki uyuşmazlığın esasının mahkemeler tarafından çözüme bağlanması halinde uygulanmalıdır. Şu kadar ki, hakem kararının iptali için yargı yoluna başvurulması halinde arabuluculuğa ilişkin hükümlerin uygulanmaması gerektiği kanaatindeyiz.

121 ÇATAKLAR, 2017, s. 433, dn. 49.

122 GÜNEŞ, 2017, s. 166. 


\section{SONUC}

Çalışan buluşlarında patent isteme hakkının çalışana veya işverene ait olması bakımından kabul edilmiş evrensel bir ilke veya kural bulunmamaktadır. Türk hukukunda, çalışanların gerçekleştirdikleri buluşlar için patent isteme hakkı mutlak emredici bir hüküm ile çalışana veya işverene tanınmamıştır. Bunun yerine, buluşun niteliği göz önünde bulundurularak, hizmet buluşları yönünden işverene hak sahipliği iddiasında bulunmak için bir yetki tanınmıştır. İşveren, bu yetki kapsamında tam hak sahipliği talebinde bulunursa patent isteme hakkı işverene ait olmaktadır. Serbest buluşlar açısından, patent isteme hakkı çalışana aittir.

Çalışan, buluş gerçekleştirdiğinde, buluşun niteliği ne olursa olsun durumu gecikmeksizin işverene bildirmekle yükümlüdür. Çalışanın bildirim yükümlülüğü, tamamlanmış bir buluş için söz konusudur. Bu nedenle, buluşun tamamlanmasından önce iş ilişkisinin sona ermesi halinde çalışanın bildirim yükümlülüğü bulunmamaktadır.

Çalışanın bildirim yükümlülügüünü yerine getirmemesi nedeniyle ortaya çıkan zarardan sorumlu olduğu, Yönetmelik md. 5/7'de öngörülmektedir. Çalışanın sorumlu olduğuna ilişkin kuralın Yönetmelik yerine SMK'de düzenlenmesi daha uygun olacaktir.

İşverenin çalışan buluşuna yönelik hak sahipliği talebi, yenilik doğurucu bir hak niteliğindedir. İşverenin bu hakkını kullanacağı zamana kadar çalışanın buluş üzerinde yaptığ1 tasarruflar işverene karşı hükümsüzdür. Üçüncü kişilerin işverene karşı bu hususta iyiniyet iddiasında bulunması SMK md. 115/4'e göre mümkün değildir.

SMK md. 115/2'de işverenin tam hak sahipliği talebinde bulunması üzerine işverene geçen hakların maddi veya manevi nitelikte olduğu belirtilmemektedir. Ancak SMK md. 90/6 hükmü dikkate alındığında, çalışanın buluşu yapan kişi olarak belirtilmesine yönelik manevi hakkın çalışana ait olduğunu ve bu hakkın devredilmediğini söylemek mümkündür.

İşveren, tam hak sahipliği talebinde bulunması halinde, kural olarak buluşa ilişkin patent başvurusunda bulunmakla yükümlüdür. İşverenin başvuruda bulunma yükümlülüğü, başvurunun TÜRKPATENT tarafından reddedilmesi halinde, karara karşı yargı 
yoluna başvurmasını da beraberinde getirir. Çünkü çalışanın buluş için patent verilmesinde hem maddi hem manevi menfaati bulunmaktadır.

İşverenin hak sahipliği talebinde bulunması halinde, çalışanın işverenden bedel isteme hakkı doğmaktadır. Çalışanın bedel isteme hakkı, işverenin hak sahipliği talebinin tam veya kısmi olmasına göre farklı usule bağlıdır. İşverenin kısmi hak talebinde bulunması halinde, taraflar arasında sözleşme hükümleri geçerli olur.

İşverenin tam hak sahipliği talebinde bulunması halinde, Yönetmelik md. 7'de işveren çalışana bedel hakkından bağımsız olarak teşvik ödülü ödemekle yükümlü tutulmaktadır. İşverenin teşvik ödülü ödeyeceğine ilişkin SMK'de bir düzenleme bulunmamaktadır. Teşvik ödülüne ilişkin Yönetmelik’teki düzenlemelerin, kanuni dayanağının bulunmayışı, zaman bakımından aynı kanun döneminde farklı uygulamalara neden oluşu ve hukuki dili yönünden eleştirilmesi mümkündür. Bu nedenle, Yönetmelik’te teşvik ödülüne yer verilmesi, sosyal bir gereklilik veya ihtiyaçtan kaynaklanmaktaysa, bu ihtiyacın kanun ile güvence altına alınması daha isabetli olur. Bununla birlikte, kamu kurum ve kuruluşlarında çalışanların teşvik ödülü talep edemeyeceğine ilişkin md. 7/2 hükmü, SMK md. 113/4'e göre hukuka uygundur.

Çalışanın bedel hakkı, taraflar arasında sözleşme ile belirlenebilir. Çalışan buluşlarına ilişkin hükümlerin emredici niteliğini dikkate alındığında bedelin belirlenmesi aşamasında, SMK ve Yönetmelik hükümlerinin veya SMK ve Yönetmelikteki standartlardan daha yüksek olması halinde işyeri uygulamasının mümkün olduğu ölçüde gözetilmesi, daha sonra ortaya çıkabilecek uyuşmazlıkların önüne geçecektir.

Tarafların bedel konusunda anlaşamamaları halinde, bedel Yönetmelik'te belirlenen usul ve esaslara göre belirlenir. Buna göre, öncelikle buluştan elde edilen gelir Yönetmelik md. 12-15'te belirlenen usule göre tespit edilir. Daha sonra, Yönetmelik md. 20/1'e göre, işverenin ve çalışanın buluşun gerçekleşmesinde katkısı dikkate alınarak buluş kategorize edilir. Ayrıca, buluştan elde edilen gelir de bedelin ödeneceği yıla ait net asgari ücret miktarının belirli katlarına göre kategorize edilir. Son olarak, buluşun ait olduğu kategori ve buluştan elde edilen gelirin asgari ücrete oranı dikkate alınarak belirlenen katsayıya göre çalışana ödenecek bedel tespit edilir. 
Kamu kurum ve kuruluşlarında çalışanlar için ödenecek bedelin tespitinde SMK'deki özel düzenlemeler ile SMK md. 113/4'e göre taraflar arasındaki sözleşme hükümleri esas alınır.

Çalışanın bedel hakkı, işveren tarafından sözleşmede belirlenen vade hükümlerine göre ifa edilir. Ancak tarafların ifa zamanı konusunda anlaşamamaları halinde, bedel, dönemli edim niteliğinde ve yıllık olarak ödenir.

Çalışanın bedel hakkı, SMK md. 118/4'e göre taraflar arasındaki iş ilişkisinden bağımsızdır. $\mathrm{Bu}$ nedenle, bedel hakkı on yıllık zamanaşımına tâbi ve SMK md. 120/2’ye göre imtiyazlı alacak niteliğine sahiptir.

İşveren ile çalışan arasında doğacak uyuşmazlıkların çözümü tahkim usulüne tâbidir. Bu hükmün etkinliğini sağlamak için kurumsal tahkim usulünün tercih edilmesi; TÜRKPATENT'in bünyesinde tahkim kurulunun oluşturulması veya mevcut kurumsal tahkim merkezleri ile anlaşma sağlanması faydalı olacaktır. 


\section{KAYNAKÇA}

BAECHTOLD, Philippe / MIYAMOTO, Tomoko / HENNINGER, Thomas, "International Patent Law: Principles, Major Instruments and Institutional Aspects”, International Intellectual Property A Handbook of Contemporary Research, (ed. GERVAIS, Daniel J), Elgar, Northampton, 2015, (s. 37-82).

BAYRAKTAR, Servi, İşçi Buluşları, Yayımlanmamış Yüksek Lisans Tezi, Ankara, Gazi Üniversitesi Sosyal Bilimler Enstitüsü, 2013.

CANBOLAT, Talat, İşçi Buluşları, Beta Yayınları, İstanbul, 2007.

ÇATAKLAR, Eda, "Sınai Mülkiyet Kanunu ile Çalışanların Tasarımları ve Buluşları Üzerindeki Hak Sahipliği Sisteminde Yapılan Değişiklikler”, 6769 Sayılı Sınai Mülkiyet Kanunu Sempozyumu, (ed. ŞEHIRALİ ÇELIK, Feyzan Hayal), Bankacıllk ve Ticaret H. Araş. E, Ankara, 2017, (s. 409-466).

ÇELIKK SIPAHİ, Özge, 551 Sayılı Kanun Hükmünde Kararname ile İşçi Buluşlarına İlişkin Patent Haklarının Korunması, Yayımlanmamış Yüksek Lisans Tezi, Ankara, Başkent Üniversitesi Sosyal Bilimler Enstitüsü, 2009.

ÇELIK, Aytekin, “Faydalı Model Belgelerinin Hükümsüzlüğü”, BATIDDER, Y11: 2011, Cilt: 27, Sayı: 1, (s. 109-153).

EREN, Fikret, Borçlar Hukuku Genel Hükümler, 23. Bask1, Yetkin Yayınları, Ankara, 2018.

FENG, Charles, China: Employee Inventions In China, http://www.mondaq.com/china/x/462864/Patent/Employee+Inventions+in+China (erişim tarihi: 15.09.2019).

GÜNEŞ, İlhami, “Türk Patent Hukuku Uygulamasında İşçi (Hizmet) Buluşları, Serbest Buluş Kavramı ve Karşılaştırmalı Hukuk”, FMR, Yı1: 2010, Cilt: 10, Sayı: 2, (s. 13-23).

GÜNEŞ, İlhami, Patent ve Faydalı Model Hukuku, Seçkin Yayıncılık, Ankara, 2017.

KAYATEKİN, Deniz, Patentin Hükümsüzlüğü, On İki Levha Yayınları, İstanbul, 2013. 
KILIÇOĞLU, Ahmet M., Borçlar Hukuku Genel Hükümler, 22. Baskı, Turhan Yayınları, Ankara, 2018.

KÖSE, Mutlu Yıldırım, Patent ve Endüstriyel Tasarım Hukukunda Gasp Davaları, Yayımlanmamış Yüksek Lisans Tezi, İstanbul, İstanbul Üniversitesi Sosyal Bilimler Enstitüsü, 2010.

KÜÇÜKALİ, Canan, "Karşılaştırmalı Hukuk ve Türk Hukukunda Çalışanların Buluşları ve Patentlenmesi”, Terazi Hukuk Dergisi, Y11: 2019, Cilt: 14, Say1: 152, (s. 759-774).

NOYAN, Erdal, Patent Hukuku, 3. Bask1, Adalet, Ankara, 2015.

ORTAN, Ali Necip, Patent Lisansı Sözleşmesi, Doğan Basımevi, Ankara, 1979.

ÖZ, Turgut, "Türk Patent Hukukunda Çalışanların Buluşları", Prof. Dr. M. İlhan Ulusan'a Armağan, (ed. ALTOP, Atilla / WELSER, Rudolf / BELLICAAN, Cüneyt/ URAL ÇINAR, Nihal / GÜMÜŞSOY KARAKURT, Güler), Cilt: 3, Seçkin Yayıncılık, Ankara, 2016, (s. 589-603).

PEBERDY, Morag / STROWEL, Alain, "Employee's Rights to Compensation for Inventions A European Perspective", Life Sciences, Y11: 2009, Say1: 10, (s. 63-70), www.practicallaw.com/9-500-8968 (erişim tarihi: 15.09.2019).

SARAÇ, Tahir, “551 Sayılı KHK'nin 11. Maddesine Göre Patent İsteme Hakkı ve Hakkın Sahibi”, Prof. Dr. Hayri DOMANiç’e 80. Yaş Günü Armağanı, (ed. KENDİGELEN, Abuzer), Cilt: 1, Beta Yayınları, İstanbul, 2001, (s. 517-546).

SARAÇ, Tahir, "Çalışanlar Tarafından Gerçekleştirilen Buluşlarda Patent Kime Verilecektir", SDÜiïBFD, Y11: 2004, Cilt: 9, Sayı: 2, (s. 257-278).

SARI, Onur, Patent Lisans Sözleşmeleri, Seçkin Yayıncılık, Ankara, 2019.

SULUK, Cahit / KARASU, Rauf / NAL, Temel, Fikri Mülkiyet Hukuku, 3. Baskı, Seçkin Yayıncılık, Ankara, 2019.

ŞEHİRALİ ÇELIKK, Feyzan Hayal, Patent Hakkının Korunması, Yayımlanmamış Yüksek Lisans Tezi, Ankara, Ankara Üniversitesi Sosyal Bilimler Enstitüsü, 1997. 
TEKINALP, Ünal, "Yeni Patent Hukukunda "Buluş Sahibi İlkesi" ve Gasp Davalarına İlişkin Bazı Sorunlar”, İHFM, Y11: 1997, Cilt: 55, Say1: 4, (s. 129-136).

TEKİNALP, Ünal, Fikri Mülkiyet Hukuku, Vedat Kitapçılık, 5. Baskı, İstanbul, 2012.

TOPÇU, Deniz, Patent Lisans Sözleşmeleri, Seçkin Yayıncılık, Ankara, 2016.

WOLK, Sanna, "Remuneration of Employee Inventors - Is There a Common European Ground? A Comparison of National Laws on Compensation of Inventors in Germany, France, Spain, Sweden and the United Kingdom”, IIC, Y11: 2011, Cilt: 42, Say1: 3, (s. 272-298).

YILDIZ, Şükrü, "551 Sayı1ı Patent Haklarının Korunması Hakkında Kanun Hükmünde Kararname Hükümlerine Göre Üniversite Mensuplarının Buluşları”, AÜEHFD, Yıl: 2002, Cilt: 6, Say1: 1-4, (s. 247-254). 